\title{
The Effect of Labor Unions on CEO Compensation
}

\author{
Qianqian Huang, Feng Jiang, Erik Lie, and Tingting Que*
}

\begin{abstract}
We find evidence that labor unions affect chief executive officer (CEO) compensation. First, we find that firms with strong unions pay their CEOs less. The negative effect is robust to various tests for endogeneity, including cross-sectional variations and a regression discontinuity design. Second, we find that CEO compensation is curbed before union contract negotiations, especially when the compensation is discretionary and the unions have a strong bargaining position. Third, we report that curbing CEO compensation mitigates the chance of a labor strike, thus providing a rationale for firms to pay CEOs less when facing strong unions.
\end{abstract}

The United Auto Workers says it knows it needs to help Detroit's automakers cut labor costs to reduce the gap in production expenses with Asian rivals. But as talks continue on new contracts, the union also is questioning why top executives at the automakers are paid what they are. (USA Today, Oct. 10, 2007)

\section{Introduction}

Executive compensation is an essential mechanism to attract, retain, and incentivize top executives. However, executive compensation is often criticized for being excessive or for creating perverse incentives, especially against the backdrop of significant compensation increases (Murphy (1999)), revelations of compensation scandals (Lie (2005)), and the alleged role of executive pay in the recent financial crisis (Bhagat and Romano (2009)). This criticism has fueled external pressure on executive compensation. In particular, Murphy ((2012), p. 47)

*Huang, qiahuang@cityu.edu.hk, College of Business, City University of Hong Kong; Jiang, fjiang6@buffalo.edu, School of Management, State University of New York-Buffalo; Lie (corresponding author), erik-lie@uiowa.edu, Tippie College of Business, University of Iowa; and Que, tingting.que@uah.edu, College of Business Administration, University of Alabama in Huntsville. We thank David Barker, Matt Billett, Ye Cai, Peter DeMarzo, Jon Garfinkel, Jarrad Harford (the editor), Randy Heron, Marcin Kacperczyk (associate editor and referee), Bill Maxwell, Yiming Qian, Tom Rietz, Tong Yao, and seminar participants at the University of Iowa for helpful suggestions and comments. 
argues that "executive contracts in publicly held corporations are ... influenced by the media, labor unions, and by political forces operating inside and outside companies." Thus, it seems important to understand whether and why firms yield to external pressure because of its potential to redistribute value.

This study focuses on the pressure from labor unions. Unions target executive compensation because they are concerned that executives receive an unfair share of cash flow and because wage inequality erodes employee morale. Anecdotal evidence supports this view. For example, the American Federation of Labor and Congress of Industrial Organizations (AFL-CIO), an umbrella federation for U.S. unions, hosts an "Executive Paywatch" feature on its Web site that claims to be "the leading watchdog critic of runaway CEO pay and its effect on growing inequality." Unions also have other powerful tools at their disposal to exert pressure on companies, most notably the right to strike, as protected under the National Labor Relations Act.

To explore the impact of unions on a firm's executive compensation policy, we first examine the relation between unionization and the level of total chief executive officer (CEO) compensation. We collect industry unionization rates from the Union Membership and Coverage Database, which annually reports the fraction of total workers in a 3-digit Census Industry Classification (CIC) industry who are represented by unions in collective bargaining agreements. Based on more than 18,000 firm-years from 1993 to 2011, we find that a 1-standarddeviation increase in the industry unionization rate is associated with roughly 9.2\% lower total CEO compensation ( $\$ 0.26$ million) for the median CEO in our sample. The negative relation between unionization and executive compensation is robust to the use of firm-level unionization data from U.S. Securities and Exchange Commission (SEC) filings, which are available for about half of our sample firms. These preliminary results weigh in on the findings in past studies: Banning and Chiles (2007) document a negative relation between unionization and executive compensation for a sample of 170 randomly selected Fortune 500 firms in 1996, whereas Singh and Agarwal (2002) find a positive relation for a sample of 86 Canadian metal-mining firms in 1996. But further analysis is required to establish causality and identify the underlying economic mechanisms. For example, it is possible that some unidentified industry or firm characteristics contribute to the lower total CEO compensation in unionized firms, or that unionization makes it difficult for firms to attract the best executive talent.

We address the identification issue in two ways. First, we explore crosssectional variations in the effects of unionization on CEO compensation. We expect that the negative impact is more pronounced when unions are relatively strong. Indeed, we find a stronger negative relation for firms located in states with no right-to-work laws and/or lower unemployment rates and for firms with more concentrated business operations. Second, we analyze CEO compensation around a set of union elections using a regression discontinuity design (RDD), and we find that passing a union election leads to a reduction in CEO compensation.

Our evidence thus far suggests that unionization induces lower CEO pay. One possibility is that the firms' decision makers are caving in to continuous union pressure for moderation in CEO pay. An alternative but not mutually exclusive possibility is that firms curtail CEO pay strategically to obtain concessions from 
unions. That is, CEO pay curtailment might be used to elicit support and cooperation from unions or to signal the need to restrain costs, and lower CEO pay among unionized firms represents a strategic choice designed to enhance shareholders' wealth.

We explore the underlying mechanism by examining CEO compensation patterns around union negotiations. In particular, we investigate whether boards attempt to strengthen firms' bargaining power by curtailing CEO pay before scheduled labor negotiations. Using collective bargaining agreement information from the Bureau of National Affairs (BNA), we document a significantly negative relation between total $\mathrm{CEO}$ pay in a given year and the negotiation ratio, defined as the percentage of employees involved in contract negotiations, in the following year. A 1-standard-deviation increase in negotiation ratio is associated with a $7.5 \%$ decline in total CEO compensation in the fiscal year prior to negotiation. This suggests that boards are more likely to curtail CEO pay when they face union contract negotiations. The empirical pattern is stronger when unions have a strong bargaining position (i.e., the firms have concentrated business operations and operate in states with no right-to-work laws and/or low unemployment rates). The pattern is also stronger for option grants, especially unscheduled grants, than for other components of CEO pay, presumably because of the ease with which firms can determine both how many options to grant and when to grant them.

In the setting of our study, we recognize that boards of directors (which formally set CEO pay) and executives (who provide input on their pay and negotiate with unions) have divergent goals. Although both parties presumably aim to keep labor costs low and union relations healthy, executives are more likely to resist a pay cut to reach these goals. We therefore examine whether the strength and independence of boards affect our results. Consistent with our conjecture, we find that firms with strong and independent boards are indeed more likely to curtail total CEO compensation to deal with powerful unions.

Finally, to investigate a possible rationale for curtailing CEO pay as a strategic tool to deal with labor unions, we examine how CEO compensation affects the decision of labor unions to initiate a strike. We find that both high CEO pay and recent increases in CEO pay raise the likelihood of a strike.

A remaining question is why union leaders do not seem to mobilize over temporary curtailment in CEO pay as they enter contract negotiations with firm managers. That is, after repeated negotiations, union leaders should have learned that CEO pay bounces back after the negotiations have concluded. ${ }^{1}$ There are several possible reasons for this apparent complacency. First, unions might be content that executive pay is curbed at least every few years, especially if they also recognize that executive pay is generally lower for unionized firms. Conversely, unions might be insulted by the failure of executives to show moderation prior to negotiations. Second, the agency problem between union leaders and workers could obscure what is rational from a union perspective. ${ }^{2}$ For example, union leaders

\footnotetext{
${ }^{1}$ In this regard, our study is particularly related to others that examine the use of accounting manipulation to temporarily deceive unions (Liberty and Zimmerman (1986), DeAngelo and DeAngelo (1991), D’Souza, Jacob, and Ramesh (2000), Bova (2013), and Comprix and Muller (2011)).

${ }^{2}$ The agency problem between union leaders and workers is widely recognized (e.g., in the early studies of Ross (1948) and Martin (1984)). The media periodically discuss the pay gap between union
} 
might recognize the strategic actions undertaken by the firm but view them as necessary to save face with workers during negotiations. Third, perhaps unions are ignorant of the trend. After all, it is hard to detect compensation patterns, especially the slow recovery after negotiations, in a single firm across a small set of negotiations. To tease out underlying patterns, our study makes use of thousands of firm-years.

As noted previously, our paper is not the first to study the relation between unionization and executive pay. Compared with earlier studies, including those by Singh and Agarwal (2002) and Banning and Chiles (2007), our study contributes to the literature by better establishing causality using triangulation tests and a regression discontinuity design. More importantly, we identify and empirically test a specific mechanism through which unions influence executive pay. In particular, we find that firms facing strong unions strategically alter executive pay to enhance bargaining power and that the failure to curtail executive compensation increases the likelihood of a labor strike.

The only study we are aware of that mentions the strategic role of CEO compensation in collective bargaining is that by DeAngelo and DeAngelo (1991). Based on a sample of 7 distressed steel firms in the 1980s, DeAngelo and DeAngelo also document a significant CEO salary cut prior to union negotiations. Our study differs in several respects. First, a large fraction of the negotiations that DeAngelo and DeAngelo study were opened early as a result of looming problems in the steel industry. The financial difficulties of the firms presumably also contributed to the CEO salary cuts, so it is unclear what role union negotiations per se played. In contrast, the union negotiations in our sample are primarily scheduled, thus allowing us to study the strategic games leading up to negotiations that are not contaminated by financial difficulties. Second, whereas DeAngelo and DeAngelo focus on base salary and bonuses, we also examine equity grants. This is critical because, in terms of both magnitude and timing, these grants are arguably the most discretionary component of CEO compensation in recent years. Third, our larger and broader sample across numerous industries allows us to conduct a more systematic and generalized study of the strategic role of CEO compensation in collective bargaining.

Our paper is related to the larger literature on the impact of labor unions on firm policies. Prior studies find that unionization affects firms' innovation activities (Hirsch (1992), Bradley, Kim, and Tian (2013)), risk-taking behavior (Chen, Kacperczyk, and Ortiz-Molina (2011), (2012)), and tax aggressiveness (Chyz, Leung, Li, and Rui (2013)). Other studies find evidence that firms take strategic actions to lower their real or apparent ability to meet union demands. These actions include leverage increases (Bronars and Deere (1991),

leaders and workers and corruption among union leaders. The Detroit News writes that "The pay disparity is taking a financial toll on many union halls" and "raises questions about whether labor leaders are sharing the economic struggles of their members" (Aug. 14, 2007). The Washington Times writes that "The average union member has no idea how much the leaders make, said Stanley Oubre, a retired Boilermaker in Louisiana - and can hardly relate" (Jan. 10, 2013). The New York Times writes that union leaders "helped corrupt contractors steal millions of dollars more from the union and its benefit funds" (Aug. 5, 2009). The National Legal and Policy Center even creates an annual "Top Ten Union Corruption Stories of the Year." 
Hanka (1998), and Matsa (2010)), curbing of cash balances (Klasa, Maxwell, and Ortiz-Molina (2009)), and the choice of accounting policies (Cullinan and Knoblett (1994), Bowen, DuCharme, and Shores (1995), D'Souza et al. (2000), and Bova (2013)).

Our paper also contributes to the literature on how external pressure affects executive compensation. Joskow, Rose, and Wolfram (1996) find that political pressures constrain CEO pay levels in the electric utility industry. Dial and Murphy (1995) describe how pressures on pay at General Dynamics led to the replacement of a controversial bonus plan with conventional stock options. Eldenburg and Krishnan (2003) show that public scrutiny leads to lower CEO pay in public hospitals. Finally, Core, Guay, and Larcker (2008) document that negative press coverage is related to excess CEO pay and option exercises, but they find little evidence that firms respond to negative press coverage by decreasing excess CEO compensation or increasing CEO turnover.

\section{Hypothesis Development and Testable Predictions}

Studies in both economics and sociology suggest that firms with unionized employees have incentives to curtail executive compensation. First, curtailing executive compensation could help manage overall labor costs. As suggested by Jensen and Murphy (1990), unions might interpret high executive compensation as a positive indicator of the firm's expected future financial performance and therefore demand wage increases. Second, curtailing executive compensation could improve union relations and limit labor disruptions. Studies show that employees generally prefer similar pay within a firm (Akerlof and Yellen (1990), Sheppard, Lewicki, and Minton (1992)). A great pay disparity between executives and other employees can make the latter feel disadvantaged and unfairly treated, which in turn can reduce productivity, increase turnover, and disrupt operations (Adams (1965), Pfeffer and Langton (1993)). This leads to our first set of testable hypotheses on the effect of unionization on executive pay:

Hypothesis 1. Unionized firms maintain lower total CEO pay.

Hypothesis 1a. The lower CEO pay for unionized firms is more pronounced when unions are relatively strong.

Hypothesis $1 b$. The lower CEO pay for unionized firms is more pronounced for the part of pay that is readily altered.

Hypothesis 1c. Passing a union election leads to a reduction in CEO pay.

There are several ways in which unions can affect CEO compensation in practice. Ertimur, Ferri, and Muslu (2011) show that union pension funds use shareholder activism, including shareholder proposals, to curb CEO pay. In this study, we focus instead on the possibility that imminent labor negotiations compel firms to curb CEO pay.

Labor negotiation outcomes can substantially affect the labor costs of the firm, the motivation and well-being of workers, and, indirectly, the financial wealth of managers, owners, and perhaps even union leaders. Thus, firms have 
an incentive to act strategically to increase the chance of moderate wage increases and meanwhile not endanger workers' motivation and sense of well-being. Such strategic actions could include temporarily raising financial leverage, minimizing cash balances, reporting lower-than-fair earnings, and curbing executive compensation. Regarding the latter, curbing executive compensation might serve as i) a symbolic concession that engenders a willingness among workers to also sacrifice for the financial health of the company or ii) a signal that executives view future prospects to be dismal, thus instigating everyone to show moderation. However, because curbing executive compensation could adversely affect firms' ability to attract and retain talented executives, the curtailment could be limited to a critical period leading up the contract negotiations. These arguments lead us to a second set of hypotheses:

Hypothesis 2. Firms curtail total CEO compensation prior to union contract negotiations.

Hypothesis $2 a$. The curtailment in CEO pay is more pronounced when unions have a strong bargaining position.

Hypothesis $2 b$. The curtailment in CEO pay is more pronounced for the part of pay that is readily altered.

We further recognize that the major players within firms differ in their roles and objectives. On the one hand, the board of directors, in its fiduciary duty to ensure that the firm is run in shareholders' long-term interest, makes overall policy decisions, provides oversight, and sets executive compensation. On the other hand, executives are in charge of the daily operations, negotiate with unions, and provide input to the board of directors on their own compensation. As such, the executives' role is more conflicted than that of the board members. Specifically, although curtailing executive compensation might improve union relations and ease union negotiations, it also hurts executives' financial wealth directly. This suggests that, compared with boards of directors, executives have less incentive to suppress their own pay even when faced with strong unions. Whether a board fulfills its fiduciary duty and curtails executive pay could very well depend on its strength and independence from executives. We therefore predict that any curtailment of executive compensation to handle powerful unions is more pronounced among firms with strong and independent boards.

Hypothesis 2c. The curtailment in CEO pay is more pronounced among firms with strong and independent boards.

To arrive at our final hypothesis, we consider the bargaining process more explicitly from the perspective of unionized workers, who desire what they perceive to be secure employment and fair wages and working conditions. As noted previously, executive compensation affects these perceptions in at least 2 ways. First, executive compensation might signal firm prospects and thus the ability of unions to extract higher wages and better working conditions without endangering future employment. Second, the pay disparity between executives and union employees affects union members' sense of fairness of their contractual terms. If union workers are displeased with the actual or proposed terms, they have a 
couple of alternative actions to take. They could seek employment elsewhere, especially if nearby employment opportunities make the switching costs reasonable. Hypotheses 1a and 2a on the power of unions capture this. Alternatively, union workers could initiate a strike, which places a financial burden on both the union (including its members) and the firm (including its ability to provide secure employment and attractive labor terms). We expect that if executive compensation affects union members' view of firm prospects and/or fairness of contractual terms, the curtailment of executive compensation reduces the likelihood of labor strikes.

Hypothesis 3. Firms that have higher CEO pay or that experience increases in CEO pay prior to union negotiations have a higher probability of union strikes.

\section{Data}

We study the population of firms covered by ExecuComp (excluding financial and utility firms) during the period 1993-2011. We require the sample firms to have available information on key variables used in our analysis, including CEO compensation, industry unionization rates, and financial information. Our data requirements yield an initial sample of 18,366 firm-year observations from 1993 to 2011.

\section{A. Unionization Data}

A union's bargaining power is highly correlated with the fraction of unionized employees in that firm. Thus, labor economists often use unionization rates as a proxy for union bargaining power. Because there is no publicly available database that provides systematic firm-level unionization information, most studies of labor unions assume industry unionization rates to be a reasonable proxy for the unionization rates of individual firms within an industry (Bronars and Deere (1991), Matsa (2010), Klasa et al. (2009), and Chen et al. (2011)). We therefore follow the literature and collect industry unionization rates from the Union Membership and Coverage Database, which reports the fraction of total workers in a 3-digit CIC industry who are represented by unions in collective bargaining agreements.

To account for intra-industry variation in union coverage, we also manually collect firm-level unionization data from firms' SEC filings, when available. Specifically, we identify firms' $10-\mathrm{K}$ filings that contain one or more of the following key words: collective bargaining, collective-bargaining, union(s), labo(u)r agreement( $(s)$, labo(u)r contract(s), labo(u)r organization(s). We then read through each of these filings to obtain union membership information. ${ }^{3}$ Because firms are not required to provide union coverage information in their public filings, we are only able to collect firm-level rates for about half of our sample firms. Among these, some firms report their unionization rates directly, whereas others only disclose the number of employees represented by various

\footnotetext{
${ }^{3}$ Union membership information is normally reported in the "Employees" section of Item 1.
} 
unions. In the latter cases, we calculate the unionization rate by scaling by the total number of employees. Of the sample of 9,013 firm-years with firm-level unionization rates, 4,862 firm-years are not covered by any collective bargaining agreements, and 4,151 firm-years have nonzero union coverage ranging from $0.003 \%$ to $96.4 \%$.

\section{B. Union Election Data}

We collect union election data from the National Labor Relations Board (NLRB). The database contains establishment-level information on union elections, including firm name, location, Standard Industrial Classification (SIC) code, petition type, election date, number of participants, and outcomes of the voting. Following Lee and Mas (2012) and Bradley et al. (2013), we merge the NLRB database with our main sample using company names. Because different abbreviations are used by these data sets, this comparison could result in matching an establishment to more than one company name. Therefore, we manually confirm each match using information on industry classification, firm location, and online resources, including LexisNexis, Factiva, and Bloomberg Businessweek. If the election outcome is unavailable or if the number of employees participating in the election is fewer than 100 , we exclude the election from our sample. When multiple elections occur within a 3-year period for a firm, we keep only the first election. This procedure yields a sample of 398 unique union elections, among which 134 elections favor unions. The unionization passage rate is $34 \%$, comparable to the rate reported by Bradley et al. (2013).

\section{Labor Contract Expirations}

We obtain data on labor contract expirations from the BNA Labor Plus database. Under the National Labor Relations Act, firms with labor union contracts are required to file notices of contract expiration with the Federal Mediation and Conciliation Service (FMCS) to help it prepare for potential strike mediation. ${ }^{4}$ These filings contain such information as employer names, contract expiration dates, bargaining unit size, and establishment size. The BNA has collected data on these contract expirations since 1990. In this study, we include collective bargaining agreements involving 500 workers or more. In comparison, Klasa et al. (2009) include contract negotiations that cover at least 1,000 workers. We choose a lower break point because firms could have multiple contract negotiations in a given year that individually involve fewer than 1,000 workers but aggregate to more than 1,000 employees. For example, in 2007, BAE Systems negotiated 2 labor contracts involving 747 and 700 employees, respectively. We then merge the BNA database with our main sample, following the matching procedure previously described. We ultimately match 518 contract expirations from the BNA database to companies covered by ExecuComp during the 1993-2011 period.

\footnotetext{
${ }^{4}$ The database includes both contentious and noncontentious negotiations. According to industry insiders with whom we have communicated, only a small minority (less than $5 \%$ ) of negotiations are not filed because a new contract is agreed upon more than 30 days before the previous contract expires.
} 


\section{Strike Data}

We collect strike data from the BNA Labor Plus database and the U.S. Bureau of Labor Statistics (BLS). These databases, constructed with data from published sources, including BNA publications, newspapers, union publications, and government reports, contain information on employer names, strike beginning and ending dates, and number of workers involved in strikes since 1990 . We follow the extant literature and focus on major strikes that involve at least 1,000 workers. After merging work stoppages with our main sample based on company names, we obtain 56 strikes during our sample period.

\section{E. Summary Statistics}

Table 1 reports summary statistics for the full sample and the subsample with data on firm-level unionization rates. All continuous variables except for unionization rates are winsorized at the 1st and 99th percentiles to reduce the influence of outliers, and all dollar values are adjusted to 2011 dollars. We construct two measures of CEO compensation: i) cash pay, defined as salary plus bonus; and ii) total pay, defined as the sum of base salary, bonus, long-term incentive payouts, the value of restricted stock grants, and the value of option grants. ${ }^{5}$

\section{TABLE 1}

\section{Summary Statistics}

Table 1 presents summary statistics for the full sample and the subsample with data on firm-level unionization rate. The full sample consists of 18,366 firm-years during the period 1993-2011. This corresponds to all firms in the ExecuComp database with no missing data on the main control variables used in our later analyses. Unionization rate is measured at the industry level and calculated as the percentage of total workers in a 3-digit Census Industry Classification $(\mathrm{CIC})$ industry who are represented by unions in collective bargaining agreements. The subsample consists of 9,013 firm-year observations, and unionization rate is calculated as the percentage of total workers represented by unions in a given firm. All continuous variables except for unionization rates are winsorized at the 1st and 99th percentiles, and all dollar values are adjusted to 2011 dollars.

CASH_PAY (total currency, in \$millions) TOTAL_PAY (ExecuComp's TDC1, in \$millions)
UNIONIZATION_RATE

CEO_TENURE

Dummy (CEO_IS_CHAIR)

TOTAL_ASSETS (in \$millions)

FIRM SIZE

BOOK-TO-MARKET

LEVERAGE

ANNUAL_RETURN

LAGGED_ANNUAL_RETURN

ROA

LAGGED ROA

STOCK_RETURN_VOLATILITY

TANGIBILITY

SALES_GROWTH

INVESTMENT

$\mathrm{R} \& \mathrm{D}$

\begin{tabular}{|c|c|c|c|c|c|}
\hline \multicolumn{3}{|c|}{$\begin{array}{l}\text { Full Sample } \\
(N=18,366)\end{array}$} & \multicolumn{3}{|c|}{$\begin{array}{c}\text { Subsample with Firm } \\
\text { Unionization Rate } \\
(N=9,013)\end{array}$} \\
\hline Mean & Median & Std. Dev. & Mean & Median & Std. Dev. \\
\hline 1.38 & 0.97 & 1.79 & 1.29 & 0.92 & 1.62 \\
\hline 5.36 & 2.85 & 12.54 & 5.01 & 2.68 & 9.60 \\
\hline 0.12 & 0.06 & 0.13 & 0.13 & 0.00 & 0.21 \\
\hline 7.92 & 5.67 & 7.47 & 8.08 & 5.92 & 7.35 \\
\hline 0.57 & 1.00 & 0.50 & 0.54 & 1.00 & 0.50 \\
\hline 6,842 & 1,585 & 20,582 & 5,047 & 1,322 & 13,129 \\
\hline 7.40 & 7.28 & 1.61 & 7.23 & 7.11 & 1.53 \\
\hline 0.63 & 0.63 & 0.26 & 0.64 & 0.64 & 0.27 \\
\hline 0.22 & 0.22 & 0.18 & 0.23 & 0.22 & 0.19 \\
\hline 0.16 & 0.09 & 0.53 & 0.17 & 0.09 & 0.56 \\
\hline 0.19 & 0.11 & 0.58 & 0.18 & 0.09 & 0.59 \\
\hline 0.04 & 0.05 & 0.11 & 0.04 & 0.05 & 0.11 \\
\hline 0.04 & 0.05 & 0.11 & 0.04 & 0.05 & 0.11 \\
\hline 0.12 & 0.11 & 0.07 & 0.13 & 0.11 & 0.07 \\
\hline 0.32 & 0.25 & 0.25 & 0.32 & 0.25 & 0.25 \\
\hline 0.07 & 0.08 & 0.22 & 0.07 & 0.08 & 0.23 \\
\hline 0.06 & 0.05 & 0.06 & 0.06 & 0.04 & 0.06 \\
\hline 0.06 & 0.00 & 0.14 & 0.06 & 0.00 & 0.15 \\
\hline
\end{tabular}

\footnotetext{
${ }^{5}$ Our compensation measures fail to capture some perks, such as executive loans, which might not be observable and the value of which is opaque. In general, opaque compensation is particularly suited for unionized firms, and it is conceivable that unionized firms rely more heavily on opaque compensation leading up to union negotiations.
} 
For the full sample, the average cash pay and average total pay are $\$ 1.38$ million and \$5.36 million, respectively, suggesting that equity-related compensation accounts for the majority of total CEO pay. The mean (median) industry unionization rate is $0.12(0.06)$, lower than the rate reported by Klasa et al. (2009). This is because we cover firms in all industries, whereas Klasa et al. focus on manufacturing firms only, whose unionization rates are generally higher. We also report firm-level unionization rates for the subsample for which this information is available. We find a very comparable mean of 0.13 but a smaller median of 0.00 . Because the distribution of the unionization rate at the firm level is skewed to the right, the median for the distribution is expected to be lower than the median for a distribution of averages for subsamples based on, for example, industry classifications.

\section{The Relation between Unionization and CEO Compensation}

\section{A. Evidence from OLS}

To test Hypothesis 1, which is that firms facing labor unions maintain lower total CEO pay, we examine whether CEOs of firms in more-unionized industries receive relatively lower observable total pay than CEOs of firms in less-unionized industries. We first conduct pooled ordinary least squares (OLS) regressions of the natural logarithm of total CEO pay on industry unionization rates and a group of control variables. The main independent variable of interest is the unionization rate in a firm's 3-digit CIC industry. We control for other economic determinants of CEO pay based on prior research in this area (e.g., Core, Holthausen, and Larcker (1999), Murphy (1999)), including firm size, growth opportunities, stock performance, accounting performance, asset tangibility, and investment rates. To address the concern that industry unionization acts as a proxy for general industry characteristics that are also correlated with total CEO compensation, we include several industry-level variables that proxy for the stage of the industry's life cycle, such as the industry's capital-to-labor ratio, industry research and development (R\&D), and industry age. We also include fixed effects for years and 2-digit SIC codes in the regressions.

Model 1 of Table 2 presents the results of our baseline model, with $p$-values based on standard errors adjusted for CIC industry clustering. The estimated coefficients of the control variables are generally in line with extant research and have the expected signs. For example, the level of total pay is positively related to firm size, growth opportunities, stock returns, cash flow volatility, and the dual CEO-chairman dummy. Turning to our variable of interest, we find that the coefficient of the industry unionization rate is negative and statistically different from 0 at the $1 \%$ level, suggesting that CEOs of firms in more-unionized industries receive lower total pay than those of firms in less-unionized industries. The impact of unionization on total CEO pay is also economically meaningful. Ceteris paribus, a 1-standard-deviation increase in industry unionization is associated with a $9.2 \%$ reduction in total compensation (TC). For comparison, we estimate that a 1-standard-deviation increase in contemporaneous annual stock 


\section{TABLE 2}

\section{CEO Compensation and Unionization}

Table 2 reports the results of ordinary least squares (OLS) regressions of CEO compensation on unionization and control variables. The full sample consists of 18,366 firm-years during the period 1993-2011, as described in Table 1. The dependent variable is the natural logarithm of CEO total compensation (TC), defined as the sum of base salary, bonus, long-term incentive payouts, the value of restricted stock grants, and the value of options (TDC1 in the ExecuComp database). The independent variable of interest is the unionization rate, measured at the 3-digit Census Industry Classification $(\mathrm{CIC})$ industry level in models $1-5$ and at the firm level in models $6-7$. Models 1 and 2 are pooled OLS regressions. Model 3 uses the firm-level time-series average of each variable. Model 4 is a Fama-MacBeth (1973) model. Model 5 uses annual means of variables for 3-digit $\mathrm{CIC}$ industries. Models 6 and 7 are OLS regressions on a subsample of 9,013 firm-years with data available on firm-level unionization rate. Year fixed effects are included in all regressions except model 3. Fixed effects for 2-digit SIC codes are included in all regressions except model 5. The regression coefficients of these fixed effects are suppressed for brevity. $p$-values based on standard errors adjusted for clustering are reported in parentheses. ${ }^{*},{ }^{* *}$, and ${ }^{* * *}$ indicate statistical significance at the $10 \%, 5 \%$, and $1 \%$ levels, respectively.

Industry Unionization Rate

\begin{tabular}{|c|c|c|c|c|c|c|c|}
\hline & \multicolumn{5}{|c|}{ Industry Unionization Rate } & \multicolumn{2}{|c|}{ Firm Unionization Rate } \\
\hline & \multicolumn{2}{|c|}{ Pooled OLS } & \multirow{2}{*}{$\frac{\begin{array}{c}\text { Firm Time- } \\
\text { Series Means }\end{array}}{3}$} & \multirow{2}{*}{$\begin{array}{c}\begin{array}{c}\text { Fama- } \\
\text { MacBeth }\end{array} \\
4\end{array}$} & \multirow{2}{*}{$\begin{array}{c}\begin{array}{c}\text { Industry } \\
\text { Level }\end{array} \\
5\end{array}$} & \multicolumn{2}{|c|}{ OLS } \\
\hline & 1 & 2 & & & & 6 & 7 \\
\hline UNIONIZATION_RATE & $\begin{array}{c}-0.737^{\star \star \star} \\
(0.001)\end{array}$ & $\begin{array}{c}-0.788^{* \star \star} \\
(0.009)\end{array}$ & $\begin{array}{l}-1.008^{* * *} \\
(0.000)\end{array}$ & $\begin{array}{c}-0.754^{\star \star} \\
(0.017)\end{array}$ & $\begin{array}{c}-0.643^{\star \star} \\
(0.013)\end{array}$ & $\begin{array}{l}-0.303^{\star \star \star} \\
(0.008)\end{array}$ & $\begin{array}{c}-0.342^{\star *} \\
(0.012)\end{array}$ \\
\hline FIRM_SIZE & $\begin{array}{l}0.461^{\star \star \star} \\
(0.000)\end{array}$ & $\begin{array}{l}0.444^{\star \star \star} \\
(0.000)\end{array}$ & $\begin{array}{l}0.487^{\star \star *} \\
(0.000)\end{array}$ & $\begin{array}{l}0.456^{\star \star \star} \\
(0.000)\end{array}$ & $\begin{array}{l}0.449^{\star \star \star} \\
(0.000)\end{array}$ & $\begin{array}{l}0.469^{\star \star \star} \\
(0.000)\end{array}$ & $\begin{array}{l}0.445^{\star \star \star} \\
(0.000)\end{array}$ \\
\hline STOCK_RETURN & $\begin{array}{l}0.253^{\star \star \star} \\
(0.000)\end{array}$ & $\begin{array}{l}0.282^{* \star \star} \\
(0.000)\end{array}$ & $\begin{array}{l}0.264^{\star * *} \\
(0.000)\end{array}$ & $\begin{array}{l}0.247^{\star \star \star} \\
(0.000)\end{array}$ & $\begin{array}{l}0.229^{\star \star \star} \\
(0.000)\end{array}$ & $\begin{array}{l}0.252^{\star \star \star} \\
(0.000)\end{array}$ & $\begin{array}{l}0.286^{\star \star \star} \\
(0.000)\end{array}$ \\
\hline LAGGED_STOCK_RETURN & $\begin{array}{l}0.114^{\star \star \star} \\
(0.000)\end{array}$ & $\begin{array}{l}0.117^{\star \star \star} \\
(0.000)\end{array}$ & $\begin{array}{l}0.125^{\star \star \star} \\
(0.000)\end{array}$ & $\begin{array}{l}0.106^{\star \star \star} \\
(0.000)\end{array}$ & $\begin{array}{l}0.143^{\text {*ᄎ }} \\
(0.000)\end{array}$ & $\begin{array}{l}0.121^{\star \star \star} \\
(0.000)\end{array}$ & $\begin{array}{l}0.136^{\star * *} \\
(0.000)\end{array}$ \\
\hline ROA & $\begin{array}{c}0.108 \\
(0.646)\end{array}$ & $\begin{array}{c}0.159 \\
(0.327)\end{array}$ & $\begin{array}{c}0.171 \\
(0.467)\end{array}$ & $\begin{array}{c}0.148 \\
(0.413)\end{array}$ & $\begin{array}{c}0.192 \\
(0.348)\end{array}$ & $\begin{array}{c}0.131 \\
(0.661)\end{array}$ & $\begin{array}{c}0.193 \\
(0.324)\end{array}$ \\
\hline LAGGED_ROA & $\begin{array}{r}-0.178 \\
(0.518)\end{array}$ & $\begin{array}{r}-0.191 \\
(0.453)\end{array}$ & $\begin{array}{c}-0.228 \\
(0.386)\end{array}$ & $\begin{array}{c}-0.201 \\
(0.252)\end{array}$ & $\begin{array}{r}-0.111 \\
(0.792)\end{array}$ & $\begin{array}{c}-0.161 \\
(0.621)\end{array}$ & $\begin{array}{r}-0.201 \\
(0.523)\end{array}$ \\
\hline LAGGED_LEVERAGE & $\begin{array}{c}-0.062 \\
(0.502)\end{array}$ & $\begin{array}{c}-0.057 \\
(0.529)\end{array}$ & $\begin{array}{c}-0.082 \\
(0.381)\end{array}$ & $\begin{array}{c}-0.099 \\
(0.399)\end{array}$ & $\begin{array}{c}-0.143 \\
(0.330)\end{array}$ & $\begin{array}{c}-0.061 \\
(0.554)\end{array}$ & $\begin{array}{c}-0.027 \\
(0.833)\end{array}$ \\
\hline $\begin{array}{l}\text { LAGGED_BOOK-TO- } \\
\text { MARKET }\end{array}$ & $\begin{array}{l}-0.719^{\star \star \star} \\
(0.000)\end{array}$ & $\begin{array}{l}-0.738^{\star \star \star} \\
(0.000)\end{array}$ & $\begin{array}{l}-0.689^{\star \star *} \\
(0.000)\end{array}$ & $\begin{array}{l}-0.672^{\star \star *} \\
(0.000)\end{array}$ & $\begin{array}{l}-0.548^{\star \star \star} \\
(0.000)\end{array}$ & $\begin{array}{l}-0.635^{\star \star \star} \\
(0.000)\end{array}$ & $\begin{array}{l}-0.763^{* \star *} \\
(0.000)\end{array}$ \\
\hline LAGGED_VOLATILITY & $\begin{array}{l}0.453^{\star \star \star} \\
(0.001)\end{array}$ & $\begin{array}{l}0.532^{* \star *} \\
(0.000)\end{array}$ & $\begin{array}{l}0.654^{* \star *} \\
(0.000)\end{array}$ & $\begin{array}{l}0.687^{* *} \\
(0.036)\end{array}$ & $\begin{array}{l}0.634^{\star \star \star} \\
(0.002)\end{array}$ & $\begin{array}{l}0.437^{\star \star} \\
(0.011)\end{array}$ & $\begin{array}{l}0.502^{* * *} \\
(0.000)\end{array}$ \\
\hline LAGGED_INVESTMENT & $\begin{array}{l}0.534^{*} \\
(0.070)\end{array}$ & $\begin{array}{c}0.444 \\
(0.137)\end{array}$ & $\begin{array}{c}0.404^{*} \\
(0.097)\end{array}$ & $\begin{array}{c}0.334 \\
(0.121)\end{array}$ & $\begin{array}{c}0.278 \\
(0.346)\end{array}$ & $\begin{array}{c}0.415 \\
(0.148)\end{array}$ & $\begin{array}{c}0.391 \\
(0.145)\end{array}$ \\
\hline LAGGED_TANGIBILITY & $\begin{array}{l}-0.442^{\star \star \star} \\
(0.000)\end{array}$ & $\begin{array}{l}-0.354^{\star \star \star} \\
(0.002)\end{array}$ & $\begin{array}{l}-0.513^{\star * \star} \\
(0.000)\end{array}$ & $\begin{array}{l}-0.347^{\star \star \star} \\
(0.001)\end{array}$ & $\begin{array}{l}-0.431^{\star \star} \\
(0.029)\end{array}$ & $\begin{array}{l}-0.371^{\star \star \star} \\
(0.004)\end{array}$ & $\begin{array}{l}-0.341^{* *} \\
(0.036)\end{array}$ \\
\hline LAGGED_SALES_GROWTH & $\begin{array}{c}0.054 \\
(0.104)\end{array}$ & $\begin{array}{c}0.034 \\
(0.401)\end{array}$ & $\begin{array}{c}0.043 \\
(0.315)\end{array}$ & $\begin{array}{c}0.032 \\
(0.518)\end{array}$ & $\begin{array}{c}0.077^{\star} \\
(0.065)\end{array}$ & $\begin{array}{c}0.047 \\
(0.108)\end{array}$ & $\begin{array}{c}0.026 \\
(0.502)\end{array}$ \\
\hline LAGGED_R\&D & $\begin{array}{c}0.003 \\
(0.316)\end{array}$ & $\begin{array}{c}0.002 \\
(0.279)\end{array}$ & $\begin{array}{c}0.002 \\
(0.665)\end{array}$ & $\begin{array}{c}0.007 \\
(0.159)\end{array}$ & $\begin{array}{c}0.005 \\
(0.149)\end{array}$ & $\begin{array}{c}0.002 \\
(0.289)\end{array}$ & $\begin{array}{c}0.002 \\
(0.159)\end{array}$ \\
\hline CEO_TENURE & $\begin{array}{c}-0.006^{\star \star} \\
(0.025)\end{array}$ & $\begin{array}{c}-0.006^{\star \star} \\
(0.034)\end{array}$ & $\begin{array}{c}-0.005^{\star *} \\
(0.039)\end{array}$ & $\begin{array}{c}-0.006^{\star \star} \\
(0.019)\end{array}$ & $\begin{array}{r}-0.004^{\star} \\
(0.075)\end{array}$ & $\begin{array}{l}-0.007^{\star \star} \\
(0.022)\end{array}$ & $\begin{array}{c}-0.008 \\
(0.024)\end{array}$ \\
\hline Dummy (CEO_IS_CHAIR) & $\begin{array}{l}0.139^{\star \star \star} \\
(0.000)\end{array}$ & $\begin{array}{l}0.153^{\star \star \star} \\
(0.000)\end{array}$ & $\begin{array}{l}0.151^{\star \star \star} \\
(0.000)\end{array}$ & $\begin{array}{l}0.138^{* * *} \\
(0.000)\end{array}$ & $\begin{array}{l}0.121^{\star \star \star} \\
(0.000)\end{array}$ & $\begin{array}{l}0.142^{\star \star \star} \\
(0.000)\end{array}$ & $\begin{array}{l}0.168^{* * *} \\
(0.000)\end{array}$ \\
\hline $\begin{array}{l}\text { INDUSTRY_CAPITAL_ } \\
\text { LABOR }\end{array}$ & $\begin{array}{c}0.001 \\
(0.211)\end{array}$ & $\begin{array}{c}0.000 \\
(0.247)\end{array}$ & $\begin{array}{c}0.001 \\
(0.172)\end{array}$ & $\begin{array}{c}0.001 \\
(0.312)\end{array}$ & $\begin{array}{c}0.001 \\
(0.166)\end{array}$ & $\begin{array}{c}0.000 \\
(0.231)\end{array}$ & $\begin{array}{c}0.000 \\
(0.291)\end{array}$ \\
\hline INDUSTRY_R\&D & $\begin{array}{c}0.001 \\
(0.611)\end{array}$ & $\begin{array}{c}-0.001 \\
(0.845)\end{array}$ & $\begin{array}{c}0.002 \\
(0.745)\end{array}$ & $\begin{array}{c}-0.002 \\
(0.644)\end{array}$ & $\begin{array}{c}0.001 \\
(0.709)\end{array}$ & $\begin{array}{r}0.0001 \\
(0.749)\end{array}$ & $\begin{array}{c}-0.002 \\
(0.556)\end{array}$ \\
\hline In(INDUSTRY_AGE) & $\begin{array}{c}-0.018 \\
(0.533)\end{array}$ & $\begin{array}{c}-0.019 \\
(0.639)\end{array}$ & $\begin{array}{c}0.017 \\
(0.698)\end{array}$ & $\begin{array}{c}-0.029 \\
(0.424)\end{array}$ & $\begin{array}{c}-0.051 \\
(0.187)\end{array}$ & $\begin{array}{r}-0.019 \\
(0.556)\end{array}$ & $\begin{array}{c}-0.021 \\
(0.573)\end{array}$ \\
\hline BOARD_SIZE & & $\begin{array}{c}0.017 \\
(0.218)\end{array}$ & & & & & $\begin{array}{c}0.019 \\
(0.247)\end{array}$ \\
\hline INDEPENDENT_BOARD & & $\begin{array}{c}-0.039 \\
(0.151)\end{array}$ & & & & & $\begin{array}{c}-0.035 \\
(0.182)\end{array}$ \\
\hline G_INDEX & & $\begin{array}{c}0.012 \\
(0.121)\end{array}$ & & & & & $\begin{array}{c}0.008 \\
(0.381)\end{array}$ \\
\hline $\begin{array}{l}\text { Year dummies } \\
\text { Industry dummies }\end{array}$ & $\begin{array}{l}\text { Yes } \\
\text { Yes }\end{array}$ & $\begin{array}{l}\text { Yes } \\
\text { Yes }\end{array}$ & $\begin{array}{l}\text { No } \\
\text { Yes }\end{array}$ & $\begin{array}{l}\text { No } \\
\text { Yes }\end{array}$ & $\begin{array}{l}\text { Yes } \\
\text { No }\end{array}$ & $\begin{array}{l}\text { Yes } \\
\text { Yes }\end{array}$ & $\begin{array}{l}\text { Yes } \\
\text { Yes }\end{array}$ \\
\hline$R^{2}$ & 0.509 & 0.479 & 0.629 & 0.445 & 0.556 & 0.454 & 0.431 \\
\hline No. of obs. & 18,366 & 8,270 & 2,154 & 19 & 2,108 & 9,013 & 4,060 \\
\hline
\end{tabular}

.


returns increases total compensation by $13.4 \%$, and a 1-standard-deviation increase in firm size $(\log$ (assets)) increases total pay by $71.5 \%$. Thus, the economic impact of unionization on CEO pay seems comparable to that of several well-known determinants of CEO pay. In model 2, we expand the baseline model by adding more governance variables and conduct the analysis on a subsample for which we have data available from RiskMetrics. The results are the same.

To further address the omitted-variable concern, we estimate a change-onchange regression to remove unobserved time-invariant factors correlated with both unionization and total CEO pay. In particular, given the limited time-series variation of industry unionization rates, we convert all variables into 2-year changes. Unreported results show that changes in total CEO pay are negatively related to changes in unionization rates, further suggesting that firms facing more powerful unions set lower levels of total CEO compensation.

Another concern is that time trends drive our findings. In fact, private-sector unionization has declined over time, whereas executive compensation has increased dramatically in the past few decades. This concern is mitigated by the year fixed effects in the regressions. However, because different industries could exhibit different time trends during our sample period, we adopt 3 approaches to strengthen our analysis. First, we conduct a time-series average regression where we convert all variables into time-series averages and estimate a pure crosssectional regression. The results are presented in model 3 of Table 2 . We find that the coefficient of unionization remains negative, with even greater magnitude and statistical significance. Second, we estimate a Fama-MacBeth (1973) model, where we correct for serial correlation with a lag of 1 . The results in model 4 confirm a significantly negative relation between unionization and total CEO pay. Finally, we repeat our OLS analysis for each year in the period 1993-2011. Untabulated results show that the coefficients of unionization rates are negative for all years and are statistically significant in 14 out of 19 years. These findings suggest that the documented negative relation is not a result of time trends.

Like other studies using industry unionization data, our analysis has a limitation in that it disregards intra-industry variation in union coverage. As a result, our findings might suffer from nontrivial measurement errors. To ensure that the estimated coefficients are not significantly biased, we convert all firm-level variables into CIC industry averages and conduct an industry-level regression. This approach can also address the issue that industries with a greater number of firms receive larger weight in earlier tests. The results are reported in model 5, with $p$-values based on standard errors adjusted for CIC industry clustering. We find that the coefficient of unionization is again negative and statistically significant, and the effect of unionization on total CEO pay is still economically large.

In model 6 of Table 2, we reestimate our baseline model using hand-collected firm-level unionization data and report $p$-values based on firm-clustered standard errors. We still find a significantly negative association between unionization and total CEO pay. All else being equal, a 1-standard-deviation increase in firm-level unionization is associated with a decrease in total CEO pay of approximately 6.4 percentage points per year. This magnitude is comparable to the 9.2 percentage points obtained using industry unionization rates. In model 7 , we add more governance controls, and our results remain the same. 
Another concern is that the lower total CEO compensation in unionized firms contributes to or is attributable to worse performance among executives in unionized firms or lower-quality executives in unionized firms. This concern is mitigated by both the inclusion of performance variables in the regression models and our later tests designed to address the identification problem. Nevertheless, we also examine the issue of CEO quality more directly. In particular, for a subsample of CEOs with biographical information from BoardEx (9,467 firm-years), we examine three measures of CEO quality: i) whether the CEO had prior CEO experience in publicly traded firms, ii) whether the CEO had an MBA degree, and iii) the number of industries (4-digit SIC) in which the CEO had worked for publicly traded firms (Custodio, Ferreira, and Matos (2013)). Among CEOs in firms with unionization below (above) the median, 31\% (27\%) had prior CEO experience, $33 \%$ (30\%) had an MBA degree, and the average number of industries they had worked in was 1.5 (1.3). On this basis, CEOs in firms with greater unionization are of lower quality. Next, we introduce these quality measures into our compensation regressions as additional independent variables. Untabulated results show that all three quality measures have positive coefficients, and those of prior CEO experience and number of prior industries are both statistically significant at the 5\% level. More importantly, the introduction of the CEO quality variables contributes only $0.5 \%$ to the explanatory power and has a trivial effect on the unionization variable, suggesting that the relation between unionization and total CEO compensation is unlikely to be attributable to CEO quality.

\section{B. Cross-Sectional Variation in the Union Effect}

To further address the identification issue, we explore cross-sectional variations in the impact of unionization on executive compensation. If the negative relation arises because boards of directors consider union pressure when setting CEO compensation, it should be more pronounced when unions have a relatively strong bargaining position relative to the firm (Hypothesis 1a).

First, we investigate how right-to-work laws, which are adopted at the state level, affect the relation between unionization and total CEO compensation. These laws state that workers should not be obligated to join or give support to a union as a condition of employment, thus weakening union power. We expect that when firms operate in states with right-to-work laws, they face less union pressure and therefore rely less on executive compensation to enhance their bargaining position. Using information from the U.S. Department of Labor, we construct an indicator variable that equals 1 if the state in which a firm operates has right-towork laws. ${ }^{6}$ We then construct an interaction term between this indicator variable and the unionization rate in the firm's industry. The model 1 results in Panel A of Table 3 show that the coefficient of the interaction term is negative and statistically significant.

Our second proxy for the bargaining environment is the local unemployment rate. Cramton and Tracy (1992) show that higher local unemployment reduces

\footnotetext{
${ }^{6}$ As of Dec. 2011, 22 states had passed right-to-work legislation. To determine the state legislation to which our sample firms are subjected, we identify historical headquarter addresses from SEC filings (mainly 10-Ks). Incidentally, we find that 141 firms relocated during our sample period.
} 


\section{TABLE 3}

\section{Determinants of the Relation between Unionization and CEO Compensation}

Table 3 reports the results of ordinary least squares (OLS) regressions of CEO compensation on unionization, interaction terms, and control variables. The full sample consists of 18,366 firm-years during the period 1993-2011, as described in Table 1. The dependent variable is the natural logarithm of CEO total compensation (TC), defined as the sum of base salary, bonus, long-term incentive payouts, the value of restricted stock grants, and the value of options (TDC1 in the ExecuComp database). The independent variables of interest are the unionization rate and its interactions with dummy variables indicating firms located in states with right-to-work laws, firms located in states with unemployment rates above the sample median, firms with business concentration indexes higher than the sample median, or firms with Z-scores below the sample median. Unionization rate is measured at the 3-digit Census Industry Classification (CIC) industry level in Panel A and at the firm level in Panel B. As in model 1 of Table 2, all regressions control for firm and industry characteristics, year fixed effects, and industry (2-digit SIC) fixed effects. The regression coefficients of these control variables are suppressed for brevity. $p$-values, which are reported in parentheses, are adjusted for industry clustering in Panel A and for firm clustering in Panel B. ${ }^{*},{ }^{* *}$, and ${ }^{* * *}$ indicate statistical significance at the $10 \%, 5 \%$, and $1 \%$ levels, respectively.

Panel A. Industry Unionization Rate

UNIONIZATION RATE

UNIONIZATION_RATE $\times$ RIGHT-TO-WORK dummy

RIGHT-TO-WORK dummy

\begin{tabular}{|c|c|c|c|c|}
\hline 1 & 2 & 3 & 4 & 5 \\
\hline $\begin{array}{c}-0.871^{\star \star \star} \\
(0.000)\end{array}$ & $\begin{array}{c}-0.807^{* \star \star} \\
(0.000)\end{array}$ & $\begin{array}{c}-0.509^{\star \star} \\
(0.024)\end{array}$ & $\begin{array}{c}-0.485^{\star \star} \\
(0.018)\end{array}$ & $\begin{array}{r}-0.521^{*} \\
(0.081)\end{array}$ \\
\hline $\begin{array}{l}0.537^{\star \star \star} \\
(0.002)\end{array}$ & & & & $\begin{array}{l}0.549^{\star \star *} \\
(0.008)\end{array}$ \\
\hline \multirow[t]{7}{*}{$\begin{array}{r}-0.062^{\star} \\
(0.076)\end{array}$} & & & & $\begin{array}{r}-0.066 \\
(0.241)\end{array}$ \\
\hline & $\begin{array}{c}0.277^{* *} \\
(0.029)\end{array}$ & & & $\begin{array}{c}0.202^{*} \\
(0.066)\end{array}$ \\
\hline & $\begin{array}{c}-0.036 \\
(0.179)\end{array}$ & & & $\begin{array}{r}-0.039 \\
(0.161)\end{array}$ \\
\hline & & $\begin{array}{c}-0.361^{\star \star} \\
(0.031)\end{array}$ & & $\begin{array}{c}-0.398^{\star *} \\
(0.038)\end{array}$ \\
\hline & & $\begin{array}{c}0.029 \\
(0.568)\end{array}$ & & $\begin{array}{c}0.038 \\
(0.454)\end{array}$ \\
\hline & & & $\begin{array}{c}-0.384^{\star \star} \\
(0.016)\end{array}$ & $\begin{array}{c}-0.396^{\star *} \\
(0.030)\end{array}$ \\
\hline & & & $\begin{array}{r}-0.021 \\
(0.536)\end{array}$ & $\begin{array}{c}-0.017 \\
(0.641)\end{array}$ \\
\hline Yes & Yes & Yes & Yes & Yes \\
\hline Yes & Yes & Yes & Yes & Yes \\
\hline Yes & Yes & Yes & Yes & Yes \\
\hline 0.511 & 0.511 & 0.508 & 0.509 & 0.511 \\
\hline 18,366 & 18,366 & 18,366 & 18,366 & 18,366 \\
\hline $\begin{array}{c}-0.442^{\star \star \star} \\
(0.000)\end{array}$ & $\begin{array}{c}-0.312^{\text {***}} \\
(0.008)\end{array}$ & $\begin{array}{c}-0.253^{\star \star} \\
(0.041)\end{array}$ & $\begin{array}{c}-0.279^{\star \star} \\
(0.038)\end{array}$ & $\begin{array}{c}-0.204 \\
(0.176)\end{array}$ \\
\hline $\begin{array}{l}0.522^{\star \star \star} \\
(0.001)\end{array}$ & & & & $\begin{array}{l}0.528^{\star \star *} \\
(0.003)\end{array}$ \\
\hline \multirow[t]{7}{*}{$\begin{array}{r}-0.065^{\star} \\
(0.082)\end{array}$} & & & & $\begin{array}{r}-0.069 \\
(0.181)\end{array}$ \\
\hline & $\begin{array}{c}0.238^{* *} \\
(0.020)\end{array}$ & & & $\begin{array}{c}0.217^{\star \star} \\
(0.040)\end{array}$ \\
\hline & $\begin{array}{c}-0.037 \\
(0.238)\end{array}$ & & & $\begin{array}{r}-0.040 \\
(0.184)\end{array}$ \\
\hline & & $\begin{array}{r}-0.209^{\star} \\
(0.074)\end{array}$ & & $\begin{array}{r}-0.206^{\star} \\
(0.081)\end{array}$ \\
\hline & & $\begin{array}{c}0.022 \\
(0.457)\end{array}$ & & $\begin{array}{c}0.012 \\
(0.488)\end{array}$ \\
\hline & & & $\begin{array}{r}-0.236^{\star} \\
(0.061)\end{array}$ & $\begin{array}{r}-0.248^{*} \\
(0.073)\end{array}$ \\
\hline & & & $\begin{array}{c}-0.046 \\
(0.238)\end{array}$ & $\begin{array}{r}-0.032 \\
(0.392)\end{array}$ \\
\hline Yes & Yes & Yes & Yes & Yes \\
\hline Yes & Yes & Yes & Yes & Yes \\
\hline Yes & Yes & Yes & Yes & Yes \\
\hline 0.462 & 0.449 & 0.459 & 0.454 & 0.462 \\
\hline 9,013 & 9,013 & 8,945 & 9,013 & 8,945 \\
\hline
\end{tabular}

Firm and industry controls

Year dummies

Industry dummies

$R^{2}$

No. of obs.

9,013

LOCAL_UNEMPLOYMENT dummy

UNIONIZATION_RATE $\times$ BUSINESS_CONCENTRATION dummy

BUSINESS_CONCENTRATION dummy

UNIONIZATION_RATE $\times$ FIRM_DISTRESS dummy

FIRM_DISTRESS dummy

Firm and industry controls

Year dummies

$R^{2}$

No. of obs.

Panel B. Firm Unionization Rate

UNIONIZATION_RATE

UNIONIZATION_RATE $\times$ RIGHT-TO-WORK dummy

RIGHT-TO-WORK dummy

UNIONIZATION_RATE $\times$ LOCAL_UNEMPLOYMENT dummy

LOCAL_UNEMPLOYMENT dummy

UNIONIZATION_RATE $\times$ BUSINESS_CONCENTRATION dummy

BUSINESS_CONCENTRATION dummy

UNIONIZATION_RATE $\times$ FIRM_DISTRESS dummy

FIRM_DISTRESS dummy 
unions' bargaining power. This also fits with our earlier discussion that local employment opportunities affect the extent to which unionized workers seek different employment when they are discontented with their labor contracts. Thus, we expect firms located in states with higher unemployment rates to be less likely to use executive compensation to strengthen their bargaining power. We collect statelevel unemployment rates from the BLS and construct a dummy variable that takes a value of 1 if the unemployment rate in the firm's state is above the sample median. Model 2 in Panel A of Table 3 shows that the coefficient of the interaction term between the industry unionization and the unemployment dummy is negative and statistically significant.

Rose (1991) argues that diversified firms have a better bargaining position relative to unions because they can cross-subsidize costs associated with union activities, such as strikes. Therefore, following Chen et al. (2011), we construct a Herfindahl index measuring the concentration of a firm's sales across its business segments. A firm is classified as having concentrated business operations if its Herfindahl index is higher than the sample median. In model 3 in Panel A of Table 3, we report that the negative relation between unionization and total CEO compensation is more pronounced for concentrated firms, providing even more evidence consistent with our conjecture.

Last, we examine whether the negative effect is stronger when lower total CEO compensation serves as credible evidence that the firm cannot comply with union demands. In particular, we investigate whether firms closer to financial distress are more likely to use lower CEO compensation to bargain with labor unions. A firm is defined as financially distressed if its Altman $Z$-score is below the sample median. The results in model 4 in Panel A of Table 3 show a significantly negative coefficient of the interaction between unionization and a distress dummy. This suggests that lower total CEO compensation provides more of a bargaining advantage for firms that face higher bankruptcy risk.

For completeness, model 5 in Panel A of Table 3 presents a regression that includes all of the aforementioned interaction terms. The results confirm our earlier findings. In Panel B of Table 3, we repeat all of these tests using unionization rates measured at the firm level and obtain the same results. Overall, the evidence in Table 3 suggests that strong unions compel firms to curtail executive compensation.

\section{Unions' Effect on Different Components of CEO Compensation}

Hypothesis $1 \mathrm{~b}$ states that the lower CEO pay is more pronounced for the part of pay that is readily altered. Unlike base salary and to some extent bonuses (which are generally tied to various predetermined performance metrics), equity grants represent a key component of discretionary compensation to executives. We therefore expect that the effect of unions on CEO compensation will be more pronounced for equity grants. To test this, we decompose total CEO compensation and repeat the earlier regressions for the different components. Table 4 reports the results.

In models 1 and 2 of Table 4, the dependent variables are the logarithm of cash pay and the logarithm of equity pay, respectively. The independent variable of interest is the industry-level unionization rate. Unionization has no significant impact on the level of cash pay, but the effect on total equity-based pay is negative 
TABLE 4

Effect of Unionization on Different Components of CEO Compensation

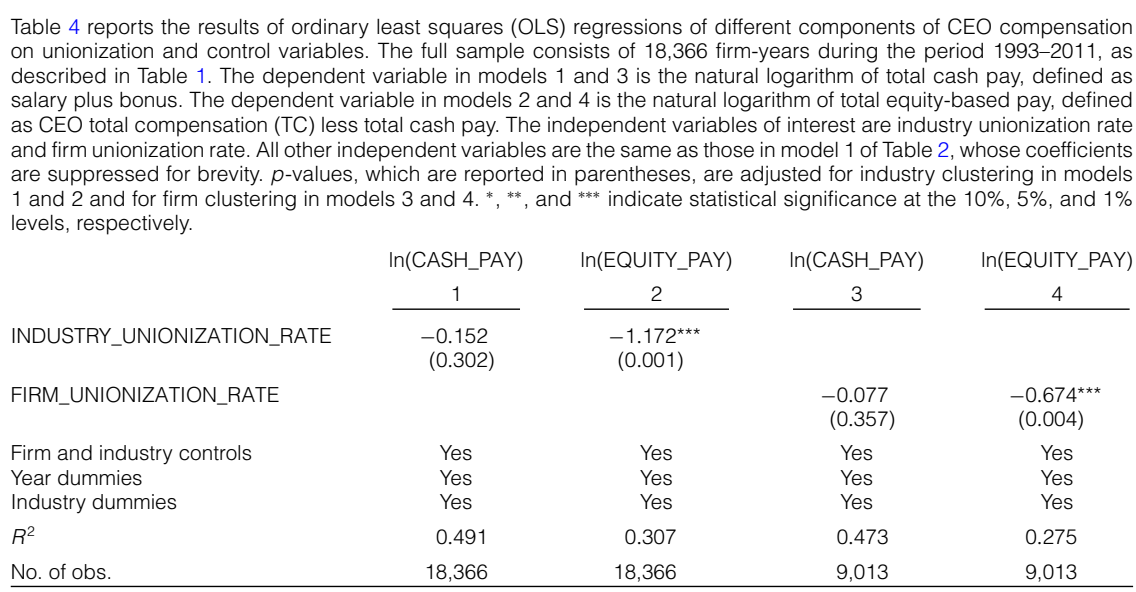

and statistically significant at the $1 \%$ level. Ceteris paribus, a 1-standard-deviation increase in industry unionization is associated with a $14.7 \%$ reduction in total equity pay. Models 3 and 4 show that the results are similar when we replace industry unionization rates with firm-level unionization rates. Untabulated results also reveal that the cross-sectional variation in the union effects in Table 3 is primarily attributable to equity pay.

\section{Union Election and CEO Compensation}

The final approach we take to establish causality is to use a regression discontinuity design (RDD) to compare CEO compensation for firms that elect to become unionized to those that vote against it (Hypothesis 1c). RDD can be used when candidates (in our case, firms) are selected for treatment (unionization) based on whether their value (fraction of votes) exceeds a certain cutoff (50\%), and several studies have utilized RDD to assess the causal impact of unionization on various firm outcomes (DiNardo and Lee (2004), Lee and Mas (2012), and Bradley et al. (2013)). A caveat is that the estimator provides a local average treatment effect (LATE) for observations at or close to the cutoff, which might differ from the average effect for observations further away from the cutoff.

A common RDD approach is to estimate a local linear regression using observations close to the cutoff. Unfortunately, there are few union elections within close proximity of the threshold (e.g., we only have 13 unique union elections in the band of vote shares from $48 \%$ to $52 \%)$. Lee and Lemieux ((2010), p. 286) state that "in order to produce a reasonable guess for the treated and untreated states at [the cutoff] with finite data, one has no choice but to use data away from the discontinuity." Therefore, we conduct a global polynomial regression using all available elections (Cuñat, Gine, and Guadalupe (2012)). Like the local approach, our global approach relies on elections that are close to the cutoff, but it "borrows" strength from elections that are further from the cutoff to estimate the effect close to the cutoff. 
Table 5 reports the regression discontinuity design (RDD) results from estimating a cubic polynomial model for a sample of firms with union elections. In models 1 and 2, the sample consists of 398 firms in the first postelection year. In models 2 and 4, the sample consists of 1,114 firm-years in the 3 postelection years. The dependent variable in models 1 and 3 and in models 2 and 4 is the natural logarithm of total cash pay and the natural logarithm of total equity-based pay, respectively. The independent variable of interest is UNIONIZATION, a dummy equal to 1 if the election favors union representation, and 0 otherwise. In addition to polynomial terms, the control variables from model 1 of Table 2 are also included; their coefficients are suppressed for brevity. $p$-values, which are reported in parentheses, are adjusted for firm clustering. ${ }^{*},{ }^{* *}$, and ${ }^{* * *}$ indicate statistical significance at the $10 \%, 5 \%$, and $1 \%$ levels, respectively.

\begin{tabular}{|c|c|c|c|c|}
\hline & \multicolumn{2}{|c|}{ Post 1 Year } & \multicolumn{2}{|c|}{ Post 3 Years } \\
\hline & In(CASH_PAY) & In(EQUITY_PAY) & In(CASH_PAY) & In(EQUITY_PAY) \\
\hline & 1 & 2 & 3 & 4 \\
\hline UNIONIZATION & $\begin{array}{l}-0.119^{\star \star} \\
(0.041)\end{array}$ & $\begin{array}{l}-0.143^{\star \star} \\
(0.048)\end{array}$ & $\begin{array}{r}-0.083^{\star} \\
(0.061)\end{array}$ & $\begin{array}{r}-0.107^{\star} \\
(0.079)\end{array}$ \\
\hline $\begin{array}{l}\text { Firm and industry controls } \\
\text { Industry and year dummies }\end{array}$ & $\begin{array}{l}\text { Yes } \\
\text { Yes }\end{array}$ & $\begin{array}{l}\text { Yes } \\
\text { Yes }\end{array}$ & $\begin{array}{l}\text { Yes } \\
\text { Yes }\end{array}$ & $\begin{array}{l}\text { Yes } \\
\text { Yes }\end{array}$ \\
\hline$R^{2}$ & 0.625 & 0.533 & 0.597 & 0.503 \\
\hline Polynomial order & Cubic & Cubic & Cubic & Cubic \\
\hline No. of obs. & 398 & 398 & 1,114 & 1,114 \\
\hline
\end{tabular}

Table 5 presents the RDD results from third-order (cubic) polynomial regressions. In all regressions, we control for the covariates used in the previous tests. In models 1 and 2, we examine CEO compensation in the first postelection year. The dependent variables are the natural logarithm of cash pay and the logarithm of equity pay, respectively. We find that the coefficients of UNIONIZATION, a dummy equal to 1 if the election favors union representation, are negative and statistically significant. In models 3 and 4, we examine CEO compensation in the 3 postelection years and find similar results. ${ }^{7}$ In terms of economic significance, ceteris paribus, passing a union election leads to an average $8.3 \%$ decline in CEO cash pay and $10.7 \%$ decline in equity pay during the 3 postelection years. The results are qualitatively similar if we use other polynomial orders. Overall, the evidence presented in this subsection suggests that a union election win leads to a decline in CEO compensation, further corroborating a negative and causal effect of unionization on CEO compensation.

\section{CEO Compensation around Contract Negotiations}

\section{A. Evidence from Total CEO Compensation}

Both anecdotal and research evidence suggests that there are several ways unions can affect CEO compensation (e.g., Ertimur et al. (2011)). In this section, we focus on one specific mechanism by examining total CEO compensation patterns around union negotiations. The main purpose is to test whether firms

\footnotetext{
${ }^{7}$ It is noteworthy that the coefficient of unionization is negative and statistically significant when examining the cash component in Table 5, whereas the coefficient of the unionization rate is negative but statistically insignificant when examining the cash component in Table 4 . We are cautious about placing too much importance on the difference in statistical significance, because it could very well be that unionization has a true underlying negative effect on the cash component in both settings. Nevertheless, one interpretation for the difference in results is that the experimental design in Table 5 better controls for endogeneity and therefore more accurately reflects the causal effect of unionization on cash compensation.
} 
strategically curtail total CEO compensation prior to union contract negotiations (Hypothesis 2).

Using labor contract expiration data from the BNA Labor Plus database, we calculate the percentage of employees involved in scheduled union contract negotiations in each year, denoted as NEGOTIATION_RATIO. Panel A of Table 6 shows that 518 firm-years in our sample have at least 1 labor contract negotiation, with an average of $16.5 \%$ of the total labor force involved in a year.

We first employ univariate tests to examine whether unionized firms rein in total CEO compensation prior to labor contract negotiations. More specifically, we examine average abnormal CEO compensation from year -2 to year +2 relative to the negotiation year. Abnormal compensation is the residual from regression model 1 of Table 2, except that the unionization rate is disregarded. Figure 1 displays the results. The average abnormal compensation is negative in all years (as a result of excluding the unionization rate from the prediction model). More importantly, there is a pronounced dip in year -1 of about $\$ 250,000$, followed by an almost complete recovery by year +1 .

Next, we turn to multivariate tests in which we regress total CEO compensation in a fiscal year on NEGOTIATION_RATIO in the subsequent fiscal year and various control variables. The estimation results are reported in Panel B of Table 6. By definition, firms with no union or with no union contract expiration during the year have a negotiation ratio of 0 . The other control variables are the same as

TABLE 6

Effect of Union Contract Negotiations on CEO Compensation

Table 6 reports the analysis of CEO compensation surrounding union contract negotiations. Panel A presents summary statistics for a sample of 518 firm-years that experience at least one union contract negotiation. The negotiation ratio is calculated as the ratio of a firm's employees involved in scheduled union contract negotiations in a given year. Panel B reports the results of ordinary least squares (OLS) regressions of CEO compensation on the negotiation ratio and control variables. The full sample consists of 18,366 firm-years during the period 1993-2011, as described in Table 1. The dependent variable is the natural logarithm of CEO total compensation (TC), defined as the sum of base salary, bonus, long-term incentive payouts, the value of restricted stock grants, and the value of options (TDC1 in the ExecuComp database). The independent variables of interest are the negotiation ratio and the unionization rate. All other independent variables are the same as those in model 1 or 2 of Table 2; their coefficients are suppressed for brevity. All independent variables are for the same year as the CEO compensation, except NEGOTIATION_RATIO, which is for the following year. $p$-values based on standard errors adjusted for firm clustering are reported in parentheses. ${ }^{*},{ }^{* *}$, and ${ }^{* * *}$ indicate statistical significance at the $10 \%, 5 \%$, and $1 \%$ levels, respectively.

Panel A. Negotiation Ratio in Firm-Years with Union Contract Negotiations

$\begin{array}{llllll}\frac{N}{518} & \frac{\text { Mean }}{0.165} & \frac{\text { P25 }}{0.025} & \frac{\text { Median }}{0.063} & \frac{\text { P75 }}{0.186} & \frac{\text { Std. Dev. }}{0.235}\end{array}$

Panel B. Relation between Negotiation Ratio and CEO Compensation

\begin{tabular}{|c|c|c|c|c|}
\hline & 1 & 2 & 3 & 4 \\
\hline NEGOTIATION_RATIO & $\begin{array}{l}-0.322^{\star \star \star} \\
(0.007)\end{array}$ & $\begin{array}{c}-0.441^{* \star *} \\
(0.009)\end{array}$ & $\begin{array}{c}-0.414^{\star *} \\
(0.022)\end{array}$ & $\begin{array}{c}-0.493^{\star \star} \\
(0.035)\end{array}$ \\
\hline INDUSTRY_UNIONIZATION_RATE & $\begin{array}{c}-0.721^{\star \star \star} \\
(0.001)\end{array}$ & $\begin{array}{c}-0.794^{\star \star \star} \\
(0.004)\end{array}$ & & \\
\hline FIRM_UNIONIZATION_RATE & & & $\begin{array}{c}-0.293^{\star *} \\
(0.016)\end{array}$ & $\begin{array}{c}-0.351^{\star \star} \\
(0.028)\end{array}$ \\
\hline $\begin{array}{l}\text { Firm and industry controls } \\
\text { Governance controls } \\
\text { Year dummies } \\
\text { Industry dummies }\end{array}$ & $\begin{array}{l}\text { Yes } \\
\text { No } \\
\text { Yes } \\
\text { Yes }\end{array}$ & $\begin{array}{l}\text { Yes } \\
\text { Yes } \\
\text { Yes } \\
\text { Yes }\end{array}$ & $\begin{array}{l}\text { Yes } \\
\text { No } \\
\text { Yes } \\
\text { Yes }\end{array}$ & $\begin{array}{l}\text { Yes } \\
\text { Yes } \\
\text { Yes } \\
\text { Yes }\end{array}$ \\
\hline$R^{2}$ & 0.507 & 0.478 & 0.455 & 0.433 \\
\hline No. of obs. & 18,366 & 8,270 & 9,013 & 4,060 \\
\hline
\end{tabular}


Abnormal CEO Compensation around Union Negotiations

Figure 1 shows average abnormal CEO compensation from year -2 to year +2 relative to the negotiation year. Abnormal compensation is the residual from regression model 1 of Table 2, except that the unionization rate is disregarded (which is why the average abnormal compensation is negative across all years).

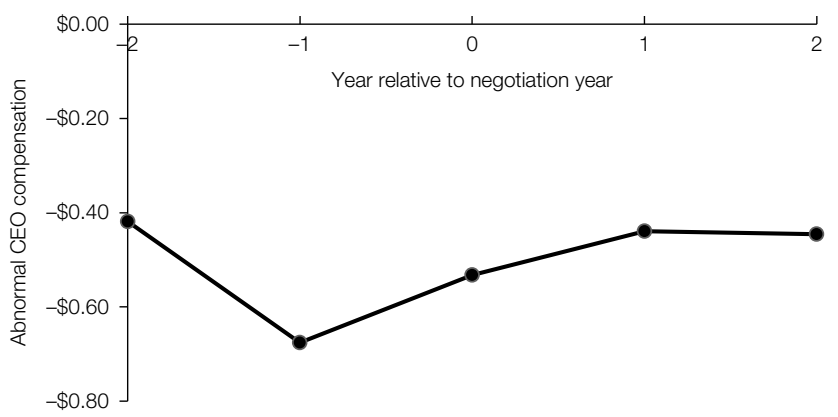

those used in Table 2, and their coefficients are suppressed for brevity. The full sample regression in model 1 shows that there is a significantly negative relation between total CEO compensation and the negotiation ratio in the following year, suggesting that firms are more likely to curtail total CEO compensation when they face union contract negotiations involving more workers. Ceteris paribus, a 1-standard-deviation increase in negotiation ratio is associated with an average $7.5 \%$ decline in total CEO compensation in the fiscal year prior to negotiation. In model 2, we conduct the same analysis on a subsample for which we have corporate governance information available. The estimated coefficient of NEGOTIATION_RATIO is again negative and statistically significant at the $1 \%$ level. In models 3 and 4, we replace the industry unionization rate with the firm-level unionization rate and repeat the analyses in models 1 and 2 . The results remain the same. In sum, the negative coefficients of NEGOTIATION_RATIO suggest that firms do indeed curtail total CEO compensation in the fiscal year preceding union contract negotiations.

It is also worth noting that the coefficients of the unionization rates in Panel B of Table 6 are negative and significantly different from 0 regardless of whether the unionization rates are estimated at the industry or firm level. Combined with the coefficients of the negotiation ratio, these results suggest that unionization is associated with lower total CEO compensation, especially in the year prior to labor negotiations but also in other years. Thus, the lower total CEO compensation for unionized firms seems to be not only a temporary phenomenon as the firms are preparing for negotiations but a persistent effect across all years. This is consistent with the findings of Ertimur et al. (2011), who show that union pension funds use shareholder proposals to constrain CEO compensation. As such, union pressure arising from labor negotiations and shareholder activism combine to limit CEO compensation and are not mutually exclusive mechanisms in affecting firms' decisions.

DeAngelo and DeAngelo (1991) report executive pay cuts prior to union negotiations for a small set of distressed firms. To test whether the effects we 
document are attributable to labor negotiations of financially distressed firms, we redo our analysis while excluding such firms. We define firms to be financially distressed if their Altman $Z$-scores are below 1.8 prior to labor contract negotiations. The results (not tabulated) are similar to those reported here for the full sample, suggesting that we are not merely documenting an effect that is specific to negotiations during times of distress.

We also examine compensation for executives other than the CEO. We conjecture that firms curtail not only CEO compensation but also that of other top executives prior to negotiations. Thus, we examine the annual compensation of the 5 highest-paid executives during the period surrounding union contract negotiations. Untabulated results indicate that top executives as a group experience a temporary curtailment in compensation prior to union contract negotiations.

\section{B. The Cross-Sectional Variation in the Effect of Labor Negotiations}

Analogous to our analysis of the relation between unionization and total CEO compensation, we explore the cross-sectional variation in the effects of union negotiation on CEO compensation. In particular, we test whether the effect of negotiation is more pronounced when the union has a strong bargaining position (Hypothesis 2a).

Table 7 presents our regression results. The choice of interaction variables and the underlying logic are the same as in Table 3. We find that the negative relation between labor negotiation and total CEO compensation is more pronounced for firms located in states with no right-to-work laws, for firms located in states with lower unemployment rates, and for firms with more concentrated business operations. The relation is likewise more pronounced for firms that are closer to financial distress. These results corroborate the claim that executive pay trends around union negotiations are designed to improve the firms' bargaining situation vis-à-vis labor unions.

\section{CEO Option Grants around Union Contract Negotiations}

We next study the pattern of different compensation components around union negotiations. Based on Hypothesis $2 \mathrm{~b}$, we expect the empirical pattern to be stronger for equity-based compensation. Moreover, because option grants represent a key part of equity pay and the board often has significant leeway in both how many options to grant and when to grant these options, we examine individual option grants most closely.

In practice, firms can issue stock options to CEOs on a scheduled or an unscheduled basis. Lie (2005) and Heron and Lie (2007) find evidence that firms opportunistically "time" unscheduled grants. This suggests that it is easier for firms to manipulate CEO compensation prior to negotiations using unscheduled option grants. Following the literature, we define option grants to be scheduled if they occur within 2 days of the 1-year anniversary of the prior year's award date; if the grants do not occur within 2 days of this anniversary or if no options were awarded during the prior year, they are defined as unscheduled. We then aggregate the value of scheduled or unscheduled options in each year using the value reported by the company. 


\begin{tabular}{|c|c|c|c|c|c|}
\hline & 1 & 2 & 3 & 4 & \\
\hline NEGOTIATION_RATIO & $\begin{array}{l}-0.511^{\star \star \star} \\
(0.001)\end{array}$ & $\begin{array}{l}-0.414^{\star \star \star} \\
(0.005)\end{array}$ & $\begin{array}{l}-0.283^{\star \star} \\
(0.032)\end{array}$ & $\begin{array}{l}-0.298^{\star \star} \\
(0.037)\end{array}$ & $\begin{array}{l}-0.772^{* * *} \\
(0.007)\end{array}$ \\
\hline $\begin{array}{l}\text { NEGOTIATION_RATIO × } \\
\text { RIGHT-TO-WORK dummy }\end{array}$ & $\begin{array}{l}0.638^{\star * \star} \\
(0.000)\end{array}$ & & & & $\begin{array}{l}0.726^{* * *} \\
(0.000)\end{array}$ \\
\hline RIGHT-TO-WORK dummy & $\begin{array}{r}-0.054^{*} \\
(0.086)\end{array}$ & & & & $\begin{array}{r}-0.051^{*} \\
(0.081)\end{array}$ \\
\hline $\begin{array}{l}\text { NEGOTIATION_RATIO } \times \\
\text { LOCAL_UNEMPLOYMENT dummy }\end{array}$ & & $\begin{array}{l}0.487^{\star \star} \\
(0.024)\end{array}$ & & & $\begin{array}{l}0.508^{* *} \\
(0.026)\end{array}$ \\
\hline LOCAL_UNEMPLOYMENT dummy & & $\begin{array}{r}-0.028 \\
(0.303)\end{array}$ & & & $\begin{array}{r}-0.023 \\
(0.281)\end{array}$ \\
\hline $\begin{array}{l}\text { NEGOTIATION_RATIO } \times \\
\text { BUSINESS_CONCENTRATION dummy }\end{array}$ & & & $\begin{array}{c}-0.327^{\star \star} \\
(0.034)\end{array}$ & & $\begin{array}{c}-0.302^{* *} \\
(0.040)\end{array}$ \\
\hline BUSINESS_CONCENTRATION dummy & & & $\begin{array}{c}0.025 \\
(0.538)\end{array}$ & & $\begin{array}{c}0.023 \\
(0.566)\end{array}$ \\
\hline $\begin{array}{l}\text { NEGOTIATION_RATIO } \times \\
\text { FIRM_DISTRESS dummy }\end{array}$ & & & & $\begin{array}{r}-0.272^{*} \\
(0.081)\end{array}$ & $\begin{array}{r}-0.117 \\
(0.659)\end{array}$ \\
\hline FIRM_DISTRESS dummy & & & & $\begin{array}{r}-0.015 \\
(0.653)\end{array}$ & $\begin{array}{r}-0.017 \\
(0.574)\end{array}$ \\
\hline $\begin{array}{l}\text { Firm and industry controls } \\
\text { Year dummies } \\
\text { Industry dummies }\end{array}$ & $\begin{array}{l}\text { Yes } \\
\text { Yes } \\
\text { Yes }\end{array}$ & $\begin{array}{l}\text { Yes } \\
\text { Yes } \\
\text { Yes }\end{array}$ & $\begin{array}{l}\text { Yes } \\
\text { Yes } \\
\text { Yes }\end{array}$ & $\begin{array}{l}\text { Yes } \\
\text { Yes } \\
\text { Yes }\end{array}$ & $\begin{array}{l}\text { Yes } \\
\text { Yes } \\
\text { Yes }\end{array}$ \\
\hline$R^{2}$ & 0.504 & 0.503 & 0.502 & 0.504 & 0.504 \\
\hline No. of obs. & 18,366 & 18,366 & 18,366 & 18,366 & 18,366 \\
\hline
\end{tabular}

Table 8 reports the results. In models 1 and 2, the dependent variable is the logarithm of cash pay and the logarithm of total equity pay, respectively. We find that the negotiation ratio has no significant impact on the level of cash pay but has a significantly negative impact on total equity-based pay. In models 3 and 4 , the dependent variable is the logarithm of scheduled grants and the logarithm of unscheduled grants, respectively. These regressions are based on the subsample of firm-years with detailed option grant information. ${ }^{8}$ We find that the value of scheduled option grants is significantly lower when there are more employees involved in labor contract negotiations in the subsequent year. The negative impact is even stronger for unscheduled option grants. Ceteris paribus, a 1-standarddeviation increase in the negotiation ratio is associated with a $28.7 \%$ reduction in total unscheduled option grants.

\section{The Effect of Board Strength and Independence}

The board of directors advises management and oversees the firm, and it is obliged to act in the interests of shareholders. It is also formally in charge

\footnotetext{
${ }^{8} \mathrm{We}$ focus the analysis after 2005 because the option grant date is not available in ExecuComp until 2006.
} 
TABLE 8

Effect of Union Contract Negotiations on Different Components of CEO Compensation

Table 8 reports the results of ordinary least squares (OLS) regressions of different components of CEO compensation on the negotiation ratio and control variables. The full sample consists of 18,366 firm-years during the period 1993-2011, as described in Table 1. The dependent variable in model 1 is the natural logarithm of total cash pay, defined as salary plus bonus. The dependent variable in model 2 is the natural logarithm of total equity-based pay, defined as CEO total compensation (TC) less total cash pay. The dependent variables in models 3 and 4 are the natural logarithm of total scheduled option grants and the natural logarithm of total scheduled option grants, respectively. The independent variable of interest is the negotiation ratio. All other independent variables are the same as those in model 1 of Table 2 , and their coefficients are suppressed for brevity. All independent variables are for the same year as the CEO compensation, except NEGOTIATION_RATIO, which is for the following year. $p$-values based on standard errors adjusted for firm clustering are reported in parentheses. ${ }^{*},{ }^{* *}$, and ${ }^{* * *}$ indicate statistical significance at the $10 \%, 5 \%$, and $1 \%$ levels, respectively.

\begin{tabular}{|c|c|c|c|c|}
\hline & In(CASH_PAY) & In(EQUITY_PAY) & $\begin{array}{l}\text { In(SCHEDULED_ } \\
\text { GRANT) }\end{array}$ & $\begin{array}{l}\text { In(UNSCHEDULED } \\
\text { GRANT) }\end{array}$ \\
\hline & 1 & 2 & 3 & 4 \\
\hline NEGOTIATION_RATIO & $\begin{array}{c}-0.053 \\
(0.415)\end{array}$ & $\begin{array}{c}-0.539^{\star \star} \\
(0.026)\end{array}$ & $\begin{array}{c}-1.788^{\star \star} \\
(0.046)\end{array}$ & $\begin{array}{c}-2.293^{\star \star \star} \\
(0.001)\end{array}$ \\
\hline $\begin{array}{l}\text { Firm and industry controls } \\
\text { Year dummies } \\
\text { Industry dummies }\end{array}$ & $\begin{array}{l}\text { Yes } \\
\text { Yes } \\
\text { Yes }\end{array}$ & $\begin{array}{l}\text { Yes } \\
\text { Yes } \\
\text { Yes }\end{array}$ & $\begin{array}{l}\text { Yes } \\
\text { Yes } \\
\text { Yes }\end{array}$ & $\begin{array}{l}\text { Yes } \\
\text { Yes } \\
\text { Yes }\end{array}$ \\
\hline $\begin{array}{l}R^{2} \\
\text { No. of obs. }\end{array}$ & $\begin{array}{r}0.399 \\
18,366\end{array}$ & $\begin{array}{r}0.319 \\
18,366\end{array}$ & $\begin{array}{l}0.174 \\
5,223\end{array}$ & $\begin{array}{l}0.141 \\
5,223\end{array}$ \\
\hline
\end{tabular}

of setting executive compensation, with the aid of input from management and compensation consultants. Our evidence thus far suggests that boards of directors curtail executive compensation when facing powerful unions, especially before important negotiations. However, even if the curtailment eases union relations and negotiations, executives have strong individual financial incentive to resist it. In this section, we explore whether the strength and independence of boards affect the curtailment of executive compensation when dealing with powerful unions, as stated in Hypothesis 2c.

We employ 4 dummy variables to measure the strength and independence of the board relative to management. NON_CEO_CHAIR indicates that the CEO is not the chairman of the board. SHORT_CEO_TENURE, a variable used by Hermalin and Weisbach (1998) and Harford and Li (2007), indicates that a CEO has below-sample-median years in serving as the CEO. A CEO with short tenure has overseen fewer director appointments and thus faces a more independent board. INDEPENDENT_BOARD indicates that the fraction of directors who are not insiders is higher than the sample median. Finally, NON_CO_OPTED_BOARD indicates that the fraction of board members who were appointed after the CEO assumed the position is below the sample median (Coles, Daniel, and Naveen (2014)). Note that data for INDEPENDENT_BOARD and NON_CO_OPTED_BOARD come from RiskMetrics and are available for fewer than half of our observations. Furthermore, whereas NON_CEO_CHAIR is designed to capture the CEO's continuous influence on board decisions, the other 3 variables are designed to capture the independence of the board members and are therefore included one at a time in our analysis.

We first examine whether the board variables affect the negative relation between unionization rate and total CEO compensation. Specifically, we expand the baseline model in Table 2 by adding the interaction terms between the industry unionization rate and the board strength variables. Panel A of Table 9 presents the 
results. The coefficients of the interaction terms based on SHORT_CEO_TENURE and NON_CO_OPTED_BOARD are both negative and statistically significant, whereas the coefficients of the other interaction terms are also negative but do not differ statistically from 0 . Next, we examine whether the board variables affect the curtailment of total CEO compensation before union negotiations. Panel B of Table 9 presents the results. Again, all coefficients of the interaction terms are negative, and they are statistically significant when the interaction terms are based on SHORT_CEO_TENURE and NON_CO_OPTED_BOARD. We interpret our results to mean that strong and independent boards (as measured by the fraction of directors appointed before the current CEO was appointed) are more likely to curtail total CEO compensation to alleviate union demands.

\section{TABLE 9}

\section{Effect of Board Strength and Independence}

Table 9 reports the results of ordinary least squares (OLS) regressions of CEO compensation on unionization variables, interaction terms, and control variables. The full sample consists of 18,366 firm-years during the period 1993-2011, as described in Table 1. The dependent variable is the natural logarithm of CEO total compensation (TC), defined as the sum of base salary, bonus, long-term incentive payouts, the value of restricted stock grants, and the value of options (TDC1 in the ExecuComp database). In Panel A, the independent variables of interest are the unionization rate and its interactions with dummy variables indicating board strength. In Panel B, the independent variables of interest are the negotiation rate and its interactions with dummy variables indicating board strength. NON CEO CHAIR is a dummy that equals 1 if a firm's CEO is not the chairman of the board. SHORT_CEO_TENURE is a dummy that equals 1 if a firm's CEO has served as the CEO for a period less than the sample median. INDEPENDENT_BOARD is a dummy that equals 1 if the fraction of directors who are not insiders is higher than the sample median. NON CO OPTED BOARD is a dummy that equals 1 if the fraction of board members who are appointed after the CEO takes the position is below the sample median. All other independent variables are the same as those in Panel A of Table 3; their coefficients are suppressed for brevity. All independent variables are for the same year as the CEO compensation, except NEGOTIATION RATIO, which is for the following year. $p$-values based on standard errors adjusted for firm clustering are reported in parentheses. *, ${ }^{* *}$, and ${ }^{* * *}$ indicate statistical significance at the $10 \%, 5 \%$, and $1 \%$ levels, respectively.

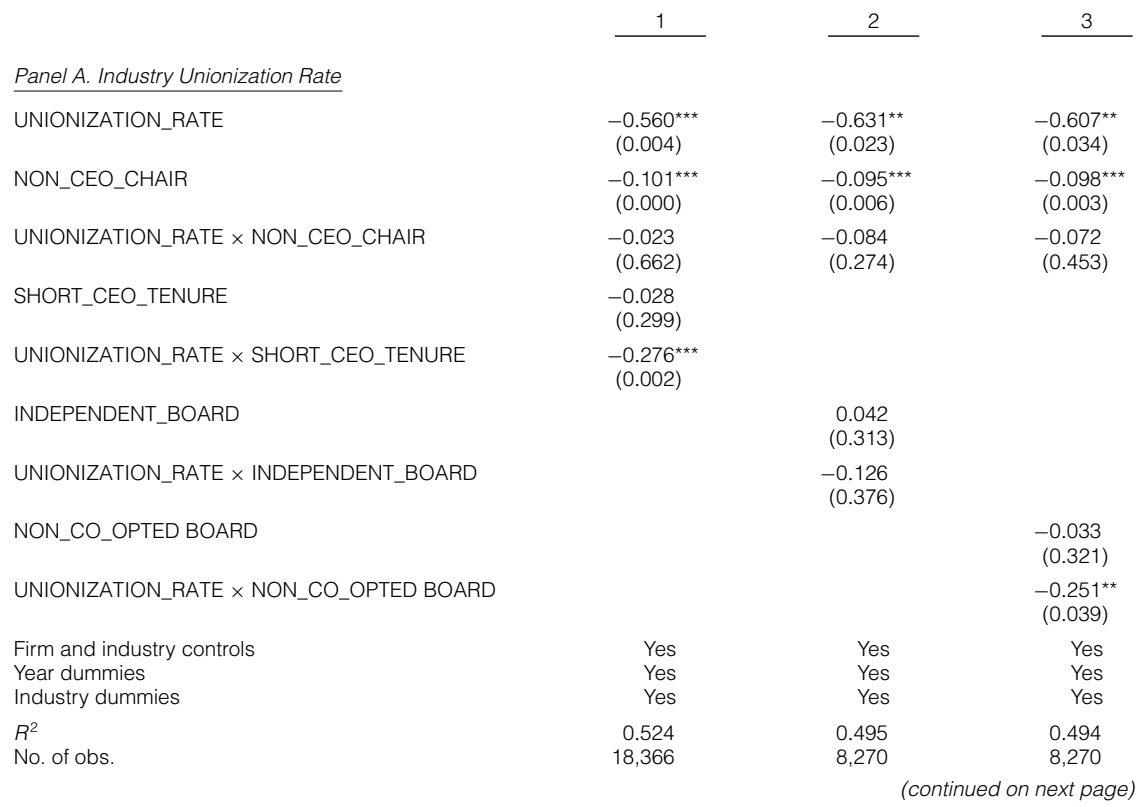


TABLE 9 (continued)

Effect of Board Strength and Independence

\begin{tabular}{|c|c|c|c|}
\hline & 1 & 2 & 3 \\
\hline \multicolumn{4}{|l|}{ Panel B. Negotiation Ratio } \\
\hline NEGOTIATION_RATIO & $\begin{array}{c}-0.238^{\star *} \\
(0.041)\end{array}$ & $\begin{array}{l}-0.411^{* *} \\
(0.015)\end{array}$ & $\begin{array}{l}-0.339^{* *} \\
(0.038)\end{array}$ \\
\hline NON_CEO_CHAIR & $\begin{array}{l}-0.111^{* \star \star} \\
(0.000)\end{array}$ & $\begin{array}{l}-0.119^{* \star \star} \\
(0.004)\end{array}$ & $\begin{array}{l}-0.111 * * * \\
(0.001)\end{array}$ \\
\hline NEGOTIATION_RATIO $\times$ NON_CEO_CHAIR & $\begin{array}{c}-0.008 \\
(0.901)\end{array}$ & $\begin{array}{c}-0.018 \\
(0.868)\end{array}$ & $\begin{array}{c}-0.029 \\
(0.826)\end{array}$ \\
\hline SHORT_CEO_TENURE & $\begin{array}{r}-0.039^{*} \\
(0.091)\end{array}$ & & \\
\hline NEGOTIATION_RATIO $\times$ SHORT_CEO_TENURE & $\begin{array}{r}-0.153^{*} \\
(0.068)\end{array}$ & & \\
\hline INDEPENDENT_BOARD & & $\begin{array}{c}0.023 \\
(0.461)\end{array}$ & \\
\hline NEGOTIATION_RATIO $\times$ INDEPENDENT_BOARD & & $\begin{array}{c}-0.038 \\
(0.738)\end{array}$ & \\
\hline NON_CO_OPTED BOARD & & & $\begin{array}{c}-0.029 \\
(0.357)\end{array}$ \\
\hline NEGOTIATION_RATIO $\times$ NON_CO_OPTED BOARD & & & $\begin{array}{r}-0.189^{*} \\
(0.074)\end{array}$ \\
\hline $\begin{array}{l}\text { Firm and industry controls } \\
\text { Year dummies } \\
\text { Industry dummies }\end{array}$ & $\begin{array}{l}\text { Yes } \\
\text { Yes } \\
\text { Yes }\end{array}$ & $\begin{array}{l}\text { Yes } \\
\text { Yes } \\
\text { Yes }\end{array}$ & $\begin{array}{l}\text { Yes } \\
\text { Yes } \\
\text { Yes }\end{array}$ \\
\hline $\begin{array}{l}R^{2} \\
\text { No. of obs. }\end{array}$ & $\begin{array}{r}0.509 \\
18,366\end{array}$ & $\begin{array}{l}0.479 \\
8,270\end{array}$ & $\begin{array}{l}0.477 \\
8,270\end{array}$ \\
\hline
\end{tabular}

\section{Indirect Effects of Unionization on Equity-Based Compensation}

Our results are consistent with firms strategically choosing lower cash and equity compensation for executives when facing strong unions. The results for the equity compensation might alternatively stem from indirect effects. First, the presence of labor unions might inflate the cost of equity, thereby lowering the stock price and the value of stock compensation. ${ }^{9}$ In support of this, Ruback and Zimmerman (1984) and Abowd (1989) show that, on average, stock values fall as a result of unionization. More recently, Lee and Mas (2012) find that union victories are associated with stock price losses and decreases in firm profitability, and Chen et al. (2011) find that the cost of equity is significantly higher in more unionized industries. A second indirect effect is that the presence of unions might reduce stock price volatility and the value of option grants. Indeed, Chen et al. (2012) find evidence that firms in more unionized industries implement less-risky investment policies.

Although the indirect effects might explain a negative relation between unionization (including union elections) and equity compensation, it is less clear how these same effects can explain the patterns in equity compensation around union negotiations. Union negotiations could temporarily affect the cost of equity,

\footnotetext{
${ }^{9}$ The effect of lower stock prices on the value of options granted at-the-money should be trivial.
} 
but stock prices should be largely unaffected because of the predictability of the negotiations. Nevertheless, to show that our results are not entirely attributable to the indirect effects via security prices, we examine the number (rather than the value) of shares and options granted to CEOs around both union elections and union negotiations.

Table 10 presents the results of our analysis of the number of shares and options granted. In models 1 and 2 of Panel A, we compare the patterns of equity grants in the first postelection year for firms that elect to unionize to those that vote against it. To do so, we employ third-order polynomial regressions. In model 1 , the dependent variable is the number of shares granted during the year. Because firms were only required to disclose the value (and not the number) of shares granted before 2006, we estimate the number of shares granted by dividing this value by the stock price at the beginning of the year. Our results are similar if we use the average monthly price or the year-end price. Because of data availability, the sample in model 1 is slightly reduced compared with that in Table 5. The coefficient of the unionization dummy is negative and statistically significant, suggesting that a union election win leads to a significant decline in the number of stocks granted to the CEO. In model 2, we examine the number of options granted after union elections. The results suggest that passing a union election likewise leads to a significant decline in the number of options granted to the CEO. In Panel B, we conduct a similar analysis around union negotiations. The dependent

TABLE 10

Number of Equity Securities Granted

Table 10 reports the analysis of equity grants around union elections and union contract negotiations. Panel A reports the regression discontinuity design (RDD) results from estimating a cubic polynomial model for a sample of firms with union elections. The full sample consists of 398 firms in the first postelection year. The dependent variable in models $1-3$ is the number of stocks granted, the number of options granted, and the ratio of total cash pay to total pay, respectively. The independent variable of interest is UNIONIZATION, a dummy equal to 1 if the election favors union representation, and 0 otherwise. In addition to polynomial terms, the control variables from model 1 of Table 2 are also included; their coefficients are suppressed for brevity. Panel B reports the ordinary least squares (OLS) results of equity grants surrounding union contract negotiations. The full sample consists of 18,366 firm-years during the period 1993-2011, as described in Table 1. The independent variable of interest is the negotiation ratio. All other independent variables are the same as those in model 1 of Table 2; their coefficients are suppressed for brevity. All independent variables are for the same year as the CEO compensation, except NEGOTIATION_RATIO, which is for the following year. $p$-values based on standard errors adjusted for firm clustering are reported in parentheses. ${ }^{*},{ }^{* *}$, and ${ }^{* * *}$ indicate statistical significance at the $10 \%, 5 \%$, and $1 \%$ levels, respectively.

\begin{tabular}{|c|c|c|c|}
\hline & $\begin{array}{c}\text { No. of Stocks } \\
\text { Granted } \\
1 \\
\end{array}$ & $\begin{array}{l}\text { No. of Options } \\
\text { Granted } \\
2 \\
\end{array}$ & $\begin{array}{c}\text { Cash Pay } \\
\text { Ratio } \\
3 \\
\end{array}$ \\
\hline \multicolumn{4}{|l|}{ Panel A. Union Elections } \\
\hline UNIONIZATION & $\begin{array}{r}-0.042^{\star} \\
(0.082)\end{array}$ & $\begin{array}{r}-0.145^{\star} \\
(0.071)\end{array}$ & $\begin{array}{c}0.034 \\
(0.421)\end{array}$ \\
\hline $\begin{array}{l}\text { Firm and industry controls } \\
\text { Industry and year dummies }\end{array}$ & $\begin{array}{l}\text { Yes } \\
\text { Yes }\end{array}$ & $\begin{array}{l}\text { Yes } \\
\text { Yes }\end{array}$ & $\begin{array}{l}\text { Yes } \\
\text { Yes }\end{array}$ \\
\hline$R^{2}$ & 0.459 & 0.403 & 0.491 \\
\hline No. of obs. & 268 & 398 & 398 \\
\hline \multicolumn{4}{|l|}{ Panel B. Union Negotiations } \\
\hline NEGOTIATION_RATIO & $\begin{array}{l}-0.031^{\star \star *} \\
(0.002)\end{array}$ & $\begin{array}{l}-0.104^{* *} \\
(0.014)\end{array}$ & $\begin{array}{c}0.084^{*} \\
(0.071)\end{array}$ \\
\hline $\begin{array}{l}\text { Firm and industry controls } \\
\text { Industry and year dummies }\end{array}$ & $\begin{array}{l}\text { Yes } \\
\text { Yes }\end{array}$ & $\begin{array}{l}\text { Yes } \\
\text { Yes }\end{array}$ & $\begin{array}{l}\text { Yes } \\
\text { Yes }\end{array}$ \\
\hline$R^{2}$ & 0.213 & 0.184 & 0.288 \\
\hline No. of obs. & 12,556 & 18,366 & 18,366 \\
\hline
\end{tabular}


variables in models 1 and 2 are the number of shares granted and the number of options granted to the CEO, respectively. We find that both the number of shares granted and the number of options granted are significantly smaller the greater the number of employees who will be involved in labor contract negotiations in the subsequent year.

As a less direct test of the effects of unionization on compensation via the cost of equity and equity prices, we examine whether firms that face union threats skew compensation away from equity in favor of cash. Model 3 of Table 10 presents the results of regressing the ratio of cash compensation to total compensation around union elections (Panel A) and union negotiations (Panel B). There is no evidence that firms skew compensation toward cash after union wins. However, there is some evidence that firms skew compensation toward cash before union negotiations. As noted previously, any indirect unionization effects should primarily be present in the union election sample. We therefore believe that the results for the union negotiations are simply attributable to the greater ease with which equity compensation can be temporarily reduced.

\section{Evidence from Labor Strikes}

Our earlier analyses suggest that firms curtail CEO compensation in anticipation of labor negotiations, ostensibly in an attempt to strengthen their bargaining power relative to that of unions. To rationalize this strategic pay curtailment, there must be some benefit for the firms. It is hard to measure the effect on the negotiation outcome because i) we do not know what the contracts would have been in the absence of the preceding CEO compensation curtailment; ii) there are many dimensions to a union contract, many of which are not readily quantifiable and/or converted into dollar figures, making it difficult to compare contract outcomes over time; and iii) we do not always have information about the outcome of the negotiations, which could limit the generalization and statistical power of the results. Instead, we focus on unions' decisions to initiate strikes in response to negotiation breakdowns, because strikes are both easy to identify and costly to the firm. We expect that firms that fail to curb CEO compensation prior to labor negotiations have a higher propensity for labor strikes (Hypothesis 3).

To test our hypothesis, we follow Klasa et al. (2009) by matching our sample firms that experience strikes with firms in the same 4-digit SIC industry that do not experience a strike in the same year. We then estimate a probit regression in which the dependent variable takes a value of 1 if a firm experiences a strike in the year, and 0 otherwise. The main independent variables of interest are the level of total CEO compensation and the change in total CEO compensation during the previous fiscal year.

We include a number of controls in the analysis. First, we use industry unionization rate to measure the ability of unions to organize the labor force. We also control for changes in the financial strength of the firm during the pre-strike year, including cash holdings, leverage, profitability, liquidity, and financial distress (proxied by Altman $Z$-score). Finally, we control for firm size, growth opportunities, whether a firm is principally located in a state with right-to-work laws, and year and industry fixed effects. 
Table 11 provides the results of our probit analysis. The results in model 1 show that there is a significantly positive association between the prior-year total CEO compensation and the likelihood that a firm subsequently experiences a strike. The prior-year change in total CEO compensation is also positively related to the likelihood of a strike. The marginal effect of CEO compensation is economically meaningful. A 1-standard-deviation increase (around the mean) in the level of total pay increases the probability of a strike by approximately $1.4 \%$, and a 1-standard-deviation increase in the change in total pay increases the strike probability by $2.7 \%$. Given that strikes are costly events for firms, our results provide a rationale for curbing executive pay prior to negotiating with unions.

\section{Effect of CEO Compensation on the Likelihood of Strike}

\begin{tabular}{|c|c|c|}
\hline & 1 & 2 \\
\hline Pre-strike-year log(PAY) & $\begin{array}{l}0.014^{\star \star} \\
(0.043)\end{array}$ & $\begin{array}{c}0.012^{*} \\
(0.061)\end{array}$ \\
\hline Pre-strike-year change in log(PAY) & $\begin{array}{l}0.027^{\star \star} \\
(0.015)\end{array}$ & $\begin{array}{l}0.025^{\star \star} \\
(0.021)\end{array}$ \\
\hline Pre-strike-year union coverage & $\begin{array}{l}0.016 \\
(0.331)\end{array}$ & $\begin{array}{c}0.017 \\
(0.293)\end{array}$ \\
\hline Pre-strike-year change in cash holdings & $\begin{array}{c}0.024^{\star \star} \\
(0.023)\end{array}$ & $\begin{array}{l}0.025^{\star \star} \\
(0.026)\end{array}$ \\
\hline Pre-strike-year change in total leverage & $\begin{array}{c}-0.002 \\
(0.467)\end{array}$ & $\begin{array}{c}-0.003 \\
(0.421)\end{array}$ \\
\hline Pre-strike-year change in operating income/Total assets & $\begin{array}{r}0.021^{*} \\
(0.078)\end{array}$ & $\begin{array}{c}0.019^{*} \\
(0.085)\end{array}$ \\
\hline Pre-strike-year change in net working capital/Total assets & $\begin{array}{l}0.025^{\star \star} \\
(0.032)\end{array}$ & $\begin{array}{l}0.028^{\star \star} \\
(0.026)\end{array}$ \\
\hline Pre-strike-year change in Altman Z-score & $\begin{array}{c}-0.014 \\
(0.231)\end{array}$ & $\begin{array}{c}-0.013 \\
(0.272)\end{array}$ \\
\hline Pre-strike-year change in book-to-market & $\begin{array}{c}-0.003 \\
(0.609)\end{array}$ & $\begin{array}{c}-0.003 \\
(0.643)\end{array}$ \\
\hline Natural logarithm of real market value of assets & $\begin{array}{l}0.036^{\star \star \star} \\
(0.001)\end{array}$ & $\begin{array}{l}0.034^{\star \star \star} \\
(0.001)\end{array}$ \\
\hline Firm is primarily located in a state with right-to-work laws & $\begin{array}{c}-0.011 \\
(0.167)\end{array}$ & $\begin{array}{c}-0.012 \\
(0.145)\end{array}$ \\
\hline Pre-strike-year stock return & & $\begin{array}{r}-0.036^{\star} \\
(0.066)\end{array}$ \\
\hline Pre-strike-year stock volatility & & $\begin{array}{c}-0.006 \\
(0.659)\end{array}$ \\
\hline Pre-strike-year inventory/Sales & & $\begin{array}{c}0.013 \\
(0.278)\end{array}$ \\
\hline Pre-strike-year fixed assets/Total assets & & $\begin{array}{c}0.007 \\
(0.187)\end{array}$ \\
\hline Pre-strike-year no. of employees/Total assets & & $\begin{array}{c}0.021 \\
(0.229)\end{array}$ \\
\hline $\begin{array}{l}\text { Year dummies } \\
\text { Industry dummies }\end{array}$ & $\begin{array}{l}\text { Yes } \\
\text { Yes }\end{array}$ & $\begin{array}{l}\text { Yes } \\
\text { Yes }\end{array}$ \\
\hline No. of obs. & 338 & 338 \\
\hline
\end{tabular}


That is, the failure to curb CEO compensation increases the probability of a breakdown in labor negotiations and a labor strike.

Turning to our control variables, we find that the estimated coefficients are generally consistent with previous studies. Notably, firms experiencing increases in cash holdings, profitability, and liquidity are subsequently more likely to have strikes (DeAngelo and DeAngelo (1991), Cramton and Tracy (1992), and Klasa et al. (2009)). Finally, in the second model, we control for more variables, including stock performance, stock return volatility, inventory ratio, and capital and labor intensity (Tracy (1986)). The results shown in the first model remain unaffected.

\section{Conclusion}

We find a significantly negative relation between executive compensation and unionization. The negative association is more pronounced for firms located in states with no right-to-work laws, for firms located in states with lower unemployment rates, for firms with more concentrated business, and for firms that are closer to financial distress. Furthermore, we find that passing a union election leads to a reduction in total CEO compensation. These findings suggest that the negative relation between CEO compensation and unionization rates is, at least partially, attributable to union pressure to constrain CEO compensation.

We next examine total CEO compensation around union contract expirations. We find that unionized firms curtail CEO compensation in the fiscal year preceding union contract negotiations. Moreover, the curtailment is greater when the unions are strong and when lower CEO compensation represents credible evidence that the firm cannot concede to union demands. We also find that the decline of executive compensation in the fiscal year preceding union contract negotiations is most evident for option grants, particularly for grants that are unscheduled.

Finally, we find that firms with higher total CEO compensation or with recent increases in total CEO compensation prior to labor negotiations are more likely to experience union strikes. This shows that labor unions respond to the level of executive compensation, thereby providing a rationale for firms to use CEO compensation as a strategic tool in their interactions with labor unions.

Our study adds to the understanding of how strategic considerations arising from collective bargaining between a firm and its labor unions affect corporate policy. In addition to manipulating actual financial flexibility, which might threaten a firm's viability, firms also use CEO compensation to improve their bargaining position with unions. In this sense, executive compensation is used not only to incentivize executives but also to create goodwill among constituencies and/or signal firm prospects to less-informed parties.

\section{References}

Abowd, J. M. "The Effect of Wage Bargains on the Stock Market Value of the Firm." American Economic Review, 79 (1989), 774-800.

Adams, J. "Inequity in Social Exchange." In Advances in Experimental Social Psychology, Vol. 2, L. Berkowitz, ed. New York, NY: Academic Press (1965), 267-299.

Akerlof, G., and J. Yellen. "The Fair Wage-Effort Hypothesis and Unemployment." Quarterly Journal of Economics, 105 (1990), 255-283. 
Banning, K., and T. Chiles. "Trade-Offs in the Labor Union-CEO Compensation Relationship.” Journal of Labor Research, 28 (2007), 347-357.

Bhagat, S., and R. Romano. "Reforming Executive Compensation: Focusing and Committing to the Long-Term." Yale Journal on Regulation, 26 (2009), 359-372.

Bova, F. "Labor Unions and Management's Incentive to Signal a Negative Outlook." Contemporary Accounting Research, 30 (2013), 14-41.

Bowen, R.; L. DuCharme; and D. Shores. "Shareholders' Implicit Claims and Accounting Method Choice." Journal of Accounting and Economics, 20 (1995), 255-295.

Bradley, D.; I. Kim; and X. Tian. "The Causal Effect of Labor Unions on Innovation.” Working Paper, Indiana University (2013).

Bronars, S., and D. Deere. "The Threat of Unionization, the Use of Debt, and the Preservation of Shareholder Wealth." Quarterly Journal of Economics, 106 (1991), 231-254.

Chen, J.; M. Kacperczyk; and H. Ortiz-Molina. "Labor Unions, Operating Flexibility, and the Cost of Equity." Journal of Financial and Quantitative Analysis, 46 (2011), 25-58.

Chen, J.; M. Kacperczyk; and H. Ortiz-Molina. "Do Non-Financial Stakeholders Affect the Pricing of Risky Debt? Evidence from Unionized Workers.” Review of Finance, 16 (2012), 347-383.

Chyz, J.; W. Leung; O. Li; and O. Rui. "Labor Unions and Tax Aggressiveness." Journal of Financial Economics, 108 (2013), 675-698.

Coles, J.; N. Daniel; and L. Naveen. "Co-Opted Boards.” Review of Financial Studies, 27 (2014), 1751-1796.

Comprix, J., and K. Muller III. "Pension Plan Accounting Estimates and the Freezing of Defined Benefit Pension Plans.” Journal of Accounting and Economics, 51 (2011), 115-133.

Core, J.; W. Guay; and D. Larcker. "The Power of the Pen and Executive Compensation.” Journal of Financial Economics, 88 (2008), 1-25.

Core, J.; R. Holthausen; and D. Larcker. "Corporate Governance, Chief Executive Officer Compensation, and Firm Performance.” Journal of Financial Economics, 51 (1999), 371-406.

Cramton, P., and J. Tracy. "Strikes and Holdouts in Wage Bargaining: Theory and Data." American Economic Review, 82 (1992), 100-121.

Cullinan, C., and J. Knoblett. "Unionization and Accounting Policy Choice: An Empirical Examination." Journal of Accounting and Public Policy, 13 (1994), 49-78.

Cuñat, V.; M. Gine; and M. Guadalupe. "The Vote Is Cast: The Effect of Corporate Governance on Shareholder Value.” Journal of Finance, 67 (2012), 1943-1977.

Custodio, C.; M. Ferreira; and P. Matos. "Generalists vs. Specialists: Lifetime Work Experience and CEO Pay.” Journal of Financial Economics, 108 (2013), 471-492.

DeAngelo, H., and L. DeAngelo. "Union Negotiations and Corporate Policy: A Study of Labor Concessions in the Domestic Steel Industry during the 1980s." Journal of Financial Economics, 30 (1991), 3-43.

Dial, J., and K. Murphy. "Incentives, Downsizing, and Value Creation at General Dynamics." Journal of Financial Economics, 37 (1995), 261-314.

DiNardo, J. K., and D. S. Lee. "Economic Impacts of New Unionization on Private Sector Employers: 1984-2001.” Quarterly Journal of Economics, 119 (2004), 1383-1441.

D’Souza, J.; J. Jacob; and K. Ramesh. "The Use of Accounting Flexibility to Reduce Labor Renegotiation Costs and Manage Earnings." Journal of Accounting and Economics, 30 (2000), 187-208.

Eldenburg, L., and R. Krishnan. "Public versus Private Governance: A Study of Incentives and Operational Performance." Journal of Accounting and Economics, 35 (2003), 377-404.

Ertimur, Y.; F. Ferri; and V. Muslu. "Shareholder Activism and CEO Pay." Review of Financial Studies, 24 (2011), 535-592.

Fama, E. F., and J. D. MacBeth. "Risk, Return, and Equilibrium: Empirical Tests." Journal of Political Economy, 81 (1973), 607-636.

Hanka, G. "Debt and the Terms of Employment." Journal of Financial Economics, 48 (1998), $245-282$.

Harford, J., and K. Li. "Decoupling CEO Wealth and Firm Performance: The Case of Acquiring CEOs." Journal of Finance, 62 (2007), 917-949.

Hermalin, B. E., and M. Weisbach. "Endogenously Chosen Boards of Directors and Their Monitoring of the CEO." American Economic Review, 88 (1998), 96-118.

Heron, R., and E. Lie. "Does Backdating Explain the Stock Price Pattern around Executive Stock Option Grants?" Journal of Financial Economics, 83 (2007), 271-295.

Hirsch, B. T. "Firm Investment Behavior and Collective Bargaining Strategy." Industrial Relations, 31 (1992), 95-121.

Jensen, M., and K. Murphy. "Performance Pay and Top-Management Incentives." Journal of Political Economy, 98 (1990), 225-264. 
Joskow, P.; N. Rose; and C. Wolfram. "Political Constraints on Executive Compensation: Evidence from the Electric Utility Industry." Rand Journal of Economic, 27 (1996), 165-182.

Klasa, S.; W. Maxwell; and H. Ortiz-Molina. "The Strategic Use of Corporate Cash Holdings in Collective Bargaining with Labor Unions.” Journal of Financial Economics, 92 (2009), 421-442.

Lee, D., and T. Lemieux. "Regression Discontinuity Designs in Economics." Journal of Economic Literature, 48 (2010), 281-355.

Lee, D., and A. Mas. "Long-Run Impacts of Unions on Firms: New Evidence from Financial Markets, 1961-1999.” Quarterly Journal of Economics, 127 (2012), 333-378.

Liberty, S., and J. Zimmerman. "Labor Union Contract Negotiations and Accounting Choices." Accounting Review, 61 (1986), 692-712.

Lie, E. "On the Timing of CEO Stock Option Awards.” Management Science, 51 (2005), 802-812.

Martin, D. L. "The Agency Problem in a Nonproprietary Theory of Union Behavior." In The Economics of Trade Unions: New Directions, J.-J. Rosa, ed. Boston, MA: Kluwer-Nijhoff (1984), 191-220.

Matsa, D. "Capital Structure as a Strategic Variable: Evidence from Collective Bargaining.” Journal of Finance, 65 (2010), 1197-1232.

Murphy, K. J. "Executive Compensation." In Handbook of Labor Economics, Vol. 3, O. Ashenfelter and D. Card, eds. Amsterdam, Netherlands: Elsevier (1999), 2485-2563.

Murphy, K. J. "Executive Compensation: Where We Are, and How We Got There." In Handbook of the Economics of Finance, G. Constantinides, M. Harris, and R. Stulz, eds. Amsterdam, Netherlands: North Holland (2012), 211-356.

Pfeffer, J., and N. Langton. "The Effect of Wage Dispersion on Satisfaction, Productivity, and Working Collaboratively: Evidence from College and University Faculty." Administrative Science Quarterly, 38 (1993), 382-407.

Rose, D. “Are Strikes Less Effective in Conglomerate Firms?" Industrial and Labor Relations Review, 45 (1991), 131-144.

Ross, A. Trade Union Wage Policy. Berkeley, CA: University of California Press (1948).

Ruback, R., and M. Zimmerman. "Unionization and Profitability: Evidence from the Capital Market." Journal of Political Economy, 92 (1984), 1134-1157.

Sheppard, B.; R. Lewicki; and J. Minton. Organizational Justice: The Search for Fairness in the Workplace. New York, NY: Lexington Books (1992).

Singh, P., and N. Agarwal. "Union Presence and Executive Compensation: An Exploratory Study." Journal of Labor Research, 23 (2002), 631-646.

Tracy, J. S. "An Investigation into the Determinants of U.S. Strike Activity." American Economic Review, 76 (1986), 423-436. 